\title{
Transient early diagenetic processes in Rhône prodelta sediments revealed in contrasting flood events
}

\author{
Pastor Lucie ${ }^{1,{ }^{*}}$, Rabouille C. ${ }^{2}$, Metzger E. ${ }^{3}$, Thibault De Chanvalon A. ${ }^{4}$, Viollier E. ${ }^{5}$, Deflandre B. ${ }^{6}$ \\ ${ }^{1}$ Institut Carnot IFREMER EDROME, Centre de Bretagne, REM/EEP, Laboratoire Environnement \\ Profond, 29280 Plouzané, France \\ ${ }^{2}$ Laboratoire des Sciences du Climat et de l'Environnement, Laboratoire mixte CNRS-CEA, Av. de la \\ Terrasse, 91190 Gif sur Yvette, France \\ ${ }^{3}$ UMR 6112, Université d'Angers, LPGN BIAF Lab Bioindicateurs Actuels \& Fossiles, CNRS, 49045 \\ Angers, France \\ ${ }^{4}$ School of Marine Science and Policy, University of Delaware, Lewes, DE 19958, USA \\ ${ }^{5}$ UMR 7154, Géochimie des Eaux, Institut de Physique du Globe de Paris, Sorbonne Paris Cité, \\ Université Paris Diderot, 75005 Paris, France \\ ${ }^{6}$ UMR 5805 EPOC - OASU, Université de Bordeaux, Allée Geoffroy St. Hilaire CS50023, 33615 \\ Pessac cedex, France \\ *Corresponding author : Lucie Pastor, email address : lucie.pastor@ifremer.fr
}

\begin{abstract}
:
Floods carry sediments to river deltas and the coastal zone, but little is known about the geochemical evolution of this particulate material deposited over a short period of time. Here, we studied two recent contrasting flood deposits in the Rhône River prodelta area (northwestern Mediterranean Sea). We monitored the porewater and solid-phase chemistry over periods ranging from a few days to 6 months after deposition. Non-steady state diagenetic processes associated with episodic deposition promote a wide spectrum of transient redox conditions in the shallow prodelta region of the Rhône. Specific attributes of diagenetic responses depend on the sources of flood material and scale (thickness) of deposition.
\end{abstract}

The first flood unit of 20-30 cm was composed of light gray mud, poor in organic carbon and rich in reactive manganese oxides. The short-term responses of early diagenetic processes contrasted with a rapid consumption of $\mathrm{O} 2$ and $\mathrm{NO} 3$ - over a few hours just after the deposition event, accompanied by a slower build-up of $\mathrm{Mn} 2+$ concentration, and a lagged response in $\mathrm{Fe} 2+$ concentration over a few days or weeks. This difference was due to the redox capacity of the sediment, evolving from oxidized, during the flood layer deposition, to more reducing conditions, after a few days or weeks, allowing Fe2+ to build up and remain in solution. Sulfate reduction may have started within a few days within the flood deposit and was greatly enhanced just below the former redox front due to a fresh input of organic matter (OM). This large production of H2S probably led to the precipitation of sulfide minerals in close vicinity to the former redox front, limiting the accumulation of $\mathrm{Fe} 2+$ and $\mathrm{H} 2 \mathrm{~S}$. The unit was sampled repeatedly three times during the six months following the flood event, and showed that manganese oxides were 
reduced at a rate of $1.8 \mathrm{mmol} \mathrm{m-2} \mathrm{d-1,} \mathrm{whereas} \mathrm{the} \mathrm{iron} \mathrm{oxide} \mathrm{concentration} \mathrm{did} \mathrm{not} \mathrm{vary} \mathrm{substantially.}$

The second flood unit was composed of darker sediment, rich in organic carbon and reactive manganese oxides. The first step of OM degradation was enhanced within this dark deposit with a high release of dissolved organic carbon (DOC). A peak in Mn2+ concentration was also measured in association with the peak in reactive manganese oxides, also showing the rapid reduction of manganese after an input of fresh reactive oxides, and its potential increased release into the water column. Finally, a peak in nitrate concentration appeared in the sediment porewater within this anoxic organic/manganese-rich layer, likely resulting from the anaerobic oxidation of ammonium by manganese oxides.

\section{Highlights}

- We present transient biogeochemical processes within two contrasting flood deposits. Reduction of manganese oxides is very efficient in the Rhône prodelta area. Episodic pulsed inputs of sediments supply the area with oxides. These inputs have impact on Mn and DOC outflux, and on $\mathrm{N}$ cycle. Oxides completely inhibit any accumulation of free sulfide in the porewater. 


\section{INTRODUCTION}

Flood events are important features that deliver large amounts of sediments into the coastal marine environment, thereby affecting its biogeochemistry (e.g. Leithold and Hope, 1999; Wheatcroft and Drake, 2003; Wheatcroft et al., 2010; Tesi et al., 2012). These events are commonly known to export sediments from land to the oceans, with preferential deposition near the river mouth, or in a depocenter, observed in numerous and different types of river deltas: e.g. the Rhône River (Miralles et al., 2006), the Po River (Palinkas et al., 2005; Tesi et al. 2012, 2013), the Têt River (Bourrin et al., 2008), the Atchafalaya River (Allison et al., 2000), and the Umpqua River (Hastings et al.,. 2012). These large and nearly instantaneous inputs of sediments play a decisive role in the distribution and fate of organic matter (OM) (e.g. Nittrouer and Sternberg, 1981; Leithold and Hope, 1999; Miserocchi et al., 2007; Tesi et al., 2008; Wheatcroft et al., 2010; Blair and Aller, 2012), its preservation being more efficient in low-energy zones and active margins (Blair and Aller, 2012). These episodic events cause major perturbations in benthic fauna assemblages (Turk and Risk, 1981; 
Peterson, 1985; Pelletier et al..4999; Thrush et al., 2003; Campbell and McKenzie, 2004;

Bonifacio et al., 2014), as well as in biogeochemical processes (Deflandre et al., 2000, 2002; Mucci et al., 2003; Chaillou et al., 2007; Tesi et al., 2012, Thibault de Chanvalon et al., 2016). The massive flash flood recorded in a Canadian fjord in 1996 led to a flood deposit of about $25 \mathrm{~cm}$ of thickness. Because this area does not undergo numerous episodic events, this deposit was studied over several years for iron $(\mathrm{Fe})$, manganese $(\mathrm{Mn})$, mercury (Hg) and arsenic (As) remobilization (Mucci et al., 2003, Mucci et al., 2015) and early diagenetic processes (Deflandre et al., 2000, 2002). One important feature in this case was the reduction of the authigenic oxyhydroxide layer that had been buried under this deposit, and trapped manganese, arsenic and iron within authigenic sulfides formed in the same zone. Nevertheless, in highly dynamic systems, the consequences of flood deposits on the biogeochemical functioning of coastal sediments and the environmental feedback in such events are still poorly understood because there are obvious logistical limitations for sampling short-lived events, which require fast response times and high-resolution sampling (Tesi et al., 2013).

Rhône River floods can account for up to $80 \%$ of the terrigenous particle inputs in the Gulf of Lions (Antonelli et al., 2008). These events are thus expected to play a major role in the fate of carbon discharged into the Rhone prodelta. Floods can differ in terms of the quantity and origin of the particles transported from the various catchment areas (Pont, 1997; Eyrolle et al., 2012). During the generalized flood of May-June 2008, there was a significant decrease in sediment oxygen uptake, followed by the re-establishment of total oxygen uptake rates just after the November 2008 flood (Cathalot et al., 2010). However, little is known about the other diagenetic processes related to the anaerobic mineralization of OM occurring after flood deposition in these transient environments. Diagenetic models of 
carbon recycling and oxygen consumption in the sediments (Pastor et al., 2011b) have indeed demonstrated that the re-oxidation and precipitation processes of manganese, iron and hydrogen sulfide $\left(\sum \mathrm{H}_{2} \mathrm{~S}\right)$ must be considered as important pathways in the fate of oxygen and organic carbon. The flood deposition of large amounts of new sediment is expected to alter these reactions and their related fluxes.

In this paper, we examined the changes in dissolved species $\left(\mathrm{Fe}^{2+}, \mathrm{Mn}^{2+}\right.$, nitrate $\left(\mathrm{NO}_{3}^{-}\right)$, ammonium $\left(\mathrm{NH}_{4}{ }^{+}\right)$, sulfate $\left(\mathrm{SO}_{4}{ }^{2-}\right)$, dissolved inorganic carbon (DIC), dissolved organic carbon (DOC)) and solid-phase properties (manganese, iron, phosphorus (P), organic carbon (OC), inorganic carbon (IC)) in the Rhône River prodelta after two different types of floods. The present study set out to: 1) characterize the composition of the particulate matter deposited during these events, and 2) define the impact of these contrasting deposits on major element cycling (C, Fe, Mn, N, S) over short (days) to long (weeks to months) periods of time.

\section{MATERIALS AND METHODS}

\subsection{Sampling}

The sampling cruises aboard the RV Tethys II (CNRS-INSU) took place in April 2007, in May-June 2008, in September 2008, in October 2008, and in December 2008. Two distinct areas were sampled (Figure 1): (1) the Rhône River prodelta located within $3 \mathrm{~km}$ of the river outlet (Stations A and AK, 23 and $45 \mathrm{~m}$ water depth, respectively), and (2) the adjacent continental shelf located within $\sim 8.5 \mathrm{~km}$ of the river outlet (Station C, $75 \mathrm{~m}$ water depth). Sampling dates together with the exact location of stations are given in Table 1.

Sediment cores were collected using an Oktopus multicorer. Up to eight undisturbed cores of $9 \mathrm{~cm}$ (inner diameter) were collected at each station with core penetration depths of 
between 20 and $50 \mathrm{~cm}$. During the cruises in April 2007, May-June and December 2008, one core was used to characterize the vertical distribution of sediment porewater and solidphase properties. Sediments were sliced under a nitrogen atmosphere, transferred into 50 $\mathrm{mL}$ polypropylene Falcon ${ }^{\mathrm{TM}}$ tubes and centrifuged under a nitrogen atmosphere at in situ temperature. Porewater samples were extracted and filtered through prewashed $0.2 \mu \mathrm{m}$ Minisart cellulose filters or through $0.7 \mu \mathrm{m}$ GF/F filters for DOC analyses. Porewater samples were separated into aliquots. One aliquot was immediately acidified to $\mathrm{pH} 2$ with Suprapur® $69 \% \mathrm{HNO}_{3}$ for the determination of $\mathrm{Fe}^{2+}$ and $\mathrm{Mn}^{2+}$. One aliquot was acidified with Suprapur ${ }^{\circledR} 85 \% \mathrm{H}_{3} \mathrm{PO}_{4}$ for the determination of DOC. One aliquot was frozen $\left(-20{ }^{\circ} \mathrm{C}\right)$ for nutrient and sulfate analyses. Finally, two aliquots were immediately analyzed for $\sum \mathrm{H}_{2} \mathrm{~S}$, and DIC. Solid-phase samples were immediately frozen.

Total suspended material (TSM) loads were measured by automatically collecting $150 \mathrm{~mL}$ of water every 90 min at the Rhône River observatory station (SORA, Arles, France). Water intake occurs $7 \mathrm{~m}$ from the right bank and $0.5 \mathrm{~m}$ under the water surface. During a flood event (discharge $>3000 \mathrm{~m}^{3} \mathrm{~s}^{-1}$ ), six samples were collected daily. The water samples were preserved with mercury (II) chloride $\left(\mathrm{HgCl}_{2}\right)$ and stored at $5^{\circ} \mathrm{C}$ until filtration using preweighed $1 \mu \mathrm{m} \mathrm{GF/F}$ filters. The TSM load was quantified as the difference between wet and dry weights. One TSM sample was recovered during the May-June 2008 flood event by the French Radioprotection and Nuclear Safety Institute (IRSN; F. Eyrolle). The collected suspended material was frozen, freeze-dried and homogeneously crushed prior to analyses of organic carbon (OC), total carbon (TC), particulate Mn, Fe, and phosphorus (P) content.

Mean daily discharge from the Arles gauging station were provided by the Compagnie Nationale du Rhône (CNR, http://www.cnr.tm.fr) and have been published elsewhere 
(Eyrolle et al., 2012). Daily TSM load measurements were provided by the SORA observatory station.

\subsection{Sediment solid-phase analyses}

Sediment porosity was calculated from the percentage water loss after freeze-drying using a sediment bulk density of $2.65 \mathrm{~g} \mathrm{~cm}^{-3}$. Sediment $\mathrm{OC}$ was determined on freeze-dried samples, which were homogeneously crushed and precisely weighed $( \pm 0.001 \mathrm{mg}$ dry weight (DW)) before acidification with $8 \%$ phosphoric acid $\left(\mathrm{H}_{3} \mathrm{PO}_{4}\right)$ (overnight) to remove carbonates. Another non-acidified subsample was used for the determination of TC. Samples were run in an automatic CHNS-Thermofisher analyzer. IC was calculated as the difference between TC and OC. Precision was typically within $2 \%$.

Chemical extractions were used to determine the solid-phase (particulate) $\mathrm{Mn}, \mathrm{Fe}$ and $\mathrm{P}$ content. We also used a certified sediment (MESS-3, NRC-CNRC) to check the repeatability of the extractions through time. The global variability of MESS-3 was around 5\% (standard error). The most reactive fractions, amorphous manganese and iron oxides, respectively $\mathrm{Mn}_{\mathrm{Asc}}$ and $\mathrm{Fe}_{\mathrm{Asc}}$, and associated elements $\left(\mathrm{P}_{\mathrm{Asc}}\right)$ were extracted with an ascorbate reagent for 24 h (Anschutz et al., 1998; Kostka and Luther, 1994; Anschutz et al., 2000). A second extraction on a separate aliquot was carried out with $1 \mathrm{~N} \mathrm{HCl}$ for $24 \mathrm{~h}$ to determine the acid-soluble fraction of manganese, iron and phosphorus (respectively $\mathrm{Mn}_{\mathrm{HCl}}$, $\mathrm{Fe}_{\mathrm{HCl}}$, and $\mathrm{P}_{\mathrm{HCl}}$ ). The acid-soluble phase represents an operationally defined fraction comprising amorphous and crystalline iron and manganese oxyhydroxides, carbonates, and hydrous aluminosilicates, but may not include the oxidation products of iron monosulfides (Raiswell et al., 1994). Mn and Fe were measured by flame atomic absorption spectroscopy (FAAS), whereas $\mathrm{P}$ was analyzed by colorimetry using a modification of the Murphy and 
Riley (1962) method, as reported in Deborde et al. (2007) for soluble reactive P. All solidphase measurements were corrected for sea-salt content.

\subsection{Porewater analyses}

Samples of bottom water and sediment porewater were analyzed for nitrate (Grasshoff, 1983), ammonium (Grasshoff and Johannsen, 1972; Koroleff, 1969) and phosphate (Murphy and Riley, 1962) on a Seal Quattro-AXFLOW autoanalyzer. A certified standard (MOOS, National Research Council Canada) was used to check the accuracy of nitrate and phosphate concentrations $(<2 \%)$. Sulfide was analyzed photometrically using the methylene blue method (Cline, 1969) with a detection limit of $\sim 1 \mu \mathrm{M}$, and sulfate by precipitation with barium chloride $(\mathrm{BaCl})$ (Tabatabai, 1974). DIC (DIC $=\mathrm{CO}_{2}+\mathrm{HCO}_{3}{ }^{-}+$ $\mathrm{CO}_{3}{ }^{2-}$ ) was measured using a flow injection analysis system with conductivity detection as described by Hall and Aller (1992), with a precision of $2 \%$. DOC was measured using a Schimadzu TOC-VCSH. Acidified subsamples were analyzed for $\mathrm{Fe}^{2+}$ and $\mathrm{Mn}^{2+}$ by graphite furnace AAS, using a Solaar AAS (Thermo Fisher Scientific) or using the ferrozine method (Viollier et al., 2000).

\subsection{Stock calculation}

Stocks of sulfate $\left(\mathrm{S}\right.$ in $\mathrm{mmol} \mathrm{m}^{-2}$ ) were calculated using the following formula: $\mathrm{S}=$ $\Sigma \mathrm{Ci}^{*} \Delta \mathrm{xi}^{*} \Phi \mathrm{i}$, where $\mathrm{Ci}$ is the concentration in $\mathrm{mM}$, $\Phi \mathrm{i}$ the measured porosity, and $\Delta \mathrm{xi}$ the thickness of sediment layer i $(6 \mathrm{~cm})$. Stocks were calculated at Station A below the former redox front, on the 29 May and the 8 June. Then, from these stocks, the sulfate consumption rate was calculated using the difference between the two stocks over 10 days. 


\section{ENVIRONMENTAL SETTING: HYDROLOGY, SEDIMENTATION, AND}

\section{FLOOD EVENTS}

Here, we present the environmental setting with an emphasis on the flood events and sediment deposition that occurred during our sampling periods.

\subsection{Background information}

The Rhône River is $812 \mathrm{~km}$ long with an annual average water discharge of $1700 \mathrm{~m}^{3} \mathrm{~s}^{-1}$ (Pont et al., 2002; Antonelli et al., 2004). The Rhône is the largest river in the

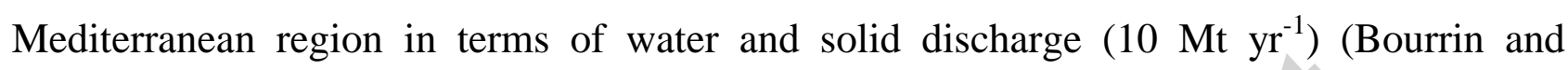
Durrieu de Madron, 2006). More than $80 \%$ of the solid load is supplied during flood events (flow greater than $3000 \mathrm{~m}^{3} \mathrm{~s}^{-1}$ ) (Ollivier et al., 2010; Eyrolle et al., 2012). Most particles are deposited near the river mouth (Figure 1), with some transfer through plume advection and secondary transport during storms southwestward (Charmasson et al., 1998; Monaco et al., 1999; Radakovitch et al., 1999; Durrieu de Madron et al., 2000; Marsset and Bellec, 2002). Particle transport paths result in sediment accumulation rates of up to $50 \mathrm{~cm} \mathrm{yr}^{-1}$ near the Rhône River mouth, dropping to $\sim 0.2 \mathrm{~cm} \mathrm{yr}^{-1}$ on the adjacent continental shelf (estimation based on ${ }^{210} \mathrm{~Pb},{ }^{137} \mathrm{Cs}$ and ${ }^{134} \mathrm{Cs}$; Calmet and Fernandez, 1990; Charmasson et al., 1998; Radakovitch et al., 1999; Miralles et al., 2005). For the Rhône River, flood events can be divided into four types (Zebracki et al., 2015): (1) oceanic floods, which generally occur in winter or in spring and result from rainfall in the northern part of the basin; ( 2) Cevenol floods, which occur mainly in autumn and result from flash-flood type storms affecting the southwestern tributaries of the Rhone River; (3) extensive Mediterranean floods, which result from precipitations affecting the right bank area of the river (Cevenol tributaries) and the sub-Alpine tributaries located on the left bank of the Rhone River; and (4) generalized floods, which mostly occur in autumn and affect both northern and southern tributaries. 


\subsection{May-June 2008}

A major generalized flood occurred in May-June 2008 with a maximum discharge of 4310 $\mathrm{m}^{3} \mathrm{~s}^{-1}$ reached on 31 May 2008 (Figure 2a). The TSM flux was high with a maximum flux of $\sim 0.3 \times 10^{6} \mathrm{t} \mathrm{d}^{-1}$ and a total delivery of $\sim 4.7 \times 10^{6}$ tons of sediment over a 16-day period (Eyrolle et al., 2012). Figure 2 shows that this flood carried particulate matter from several sub-catchments. Two major tributaries contributed to this flood event: the Durance and the Isère rivers (Figures 1 and $2 b-c$ ). The Isère substratum is mainly composed of sedimentary rocks with some siliceous crystalline and metamorphic rocks, whereas the Durance substratum is constituted of calcareous formations in the western Prealps. The opening of the Serre-Ponçon dam winnows on the Durance River caused rapid bank erosion of a high amount of particulate matter strongly dominated by carbonate phases, which were combined with the particulate matter exported by the Isère tributary leading to a significant flood deposit observed on each core sampled in the prodelta area. This "old" material was depleted in short half-life radionuclides (Eyrolle et al., 2012) and thus the flood deposit exhibited a lower-than-expected inventory compared to normal floods $\left({ }^{7} \mathrm{Be}\right.$ around $25 \mathrm{~Bq}$ $\mathrm{kg}^{-1}$ and ${ }^{234} \mathrm{Th}_{\mathrm{ex}}$ (in excess) below $100 \mathrm{~Bq} \mathrm{~kg}^{-1}$; Wu et al., 2018). This flood has thus been considered "atypical" in several studies (Cathalot et al., 2013, Eyrolle et al., 2012). A gray mud layer was observed at the top of the sediment core collected at Station A ranging from $2.5 \mathrm{~cm}$ thickness on 29 May (the flood just started) to $31.5 \mathrm{~cm}$ on 8 June at the end of the main deposition period (Table 1). Station AK, located about $20 \mathrm{~m}$ deeper in water depth, exhibited a $23 \mathrm{~cm}$ gray mud deposit on 8 June (Figure 3a).The next two expeditions in September 2008 and October 2008 occurred during a long period without flood events, allowing the study of the evolution of the May-June flood deposits. 


\subsection{December 2008}

In December 2008, sampling took place during a moderate-to-high water discharge (Figure 2a), about 26 days after a Cevenol flood (not visible in the Isère or in the Durance, Figure $2 \mathrm{~b}$ and $2 \mathrm{c}$ ) that delivered $0.4 \times 10^{6}$ tons of sediment resulting in a new flood deposit. This Cevenol flash-flood carried material from the Cevennes Mountains, mostly composed of crystalline siliceous rocks and organic debris and deposited about 10-20 $\mathrm{cm}$ of a darker flood deposit in the prodelta area (Figures 3d and 4c). At the same station, Wu et al. (2018) recorded high concentrations and inventories of ${ }^{7} \mathrm{Be}$ and ${ }^{234} \mathrm{Th}_{\mathrm{ex}}$ in December 2008 (concentrations of up to $120 \mathrm{~Bq} \mathrm{~kg}^{-1}$ and $410 \mathrm{~Bq} \mathrm{~kg}^{-1}$, respectively) directly associated with the high river flow and particulate river discharge at that time (Figure 2a). They concluded that the area was clearly influenced by the November 2008 flood.

\section{RESULTS}

Data from figures 4 and 5 are presented as supplementary material.

\subsection{The prodelta area}

\subsubsection{Chemical composition of sediment discharged during the generalized flood of 2008}

The solid-phase characteristics of sediments deposited at Station A in the Rhône prodelta area were similar to the properties of sediments retrieved from the Rhône River during the generalized flood event (Table 2), except for $\mathrm{Fe}_{\mathrm{HCl}}$, which showed lower values in the river (143 $\mu \mathrm{mol} \mathrm{g}{ }^{-1}$ vs. $196-199 \pm 9 \mu \mathrm{mol} \mathrm{g}{ }^{-1}$ in the flood deposit). The flood deposit showed low OC content (0.9-1.1\%) and high IC content (4.1-4.3\%) compared to the sediment accumulated before the flood event, hereafter named "preflood sediment" (Table 2). During this flood, the erosion of the Durance watershed led to a high export of inorganic material, thus decreasing the relative abundance of OC, and making IC a good tracer of this deposit. 
There was no significant difference in $=$ iron phases, although a significant decrease in particulate phosphorus was observed between the preflood sediment and the flood deposit (from $\mathrm{P}_{\mathrm{Asc}}=5.4$ to $1.8-2.3 \mu \mathrm{mol} \mathrm{g}{ }^{-1}$, Table 2). The $\mathrm{Fe}_{\mathrm{Asc}}: \mathrm{P}_{\mathrm{Asc}}$ ratio of $\sim 10$ in the preflood sediments increased to around 25-30 in the TSM sample and in the flood deposit.

\subsubsection{Porewater chemistry after the generalized flood deposit}

The rapid deposition of new sediments led to a clear break in the patterns in the depth profiles (Figure $4 \mathrm{~b}$ ). The $\mathrm{OC}$ mineralization products $\left(\mathrm{NH}_{4}{ }^{+}\right.$and DIC) that typically accumulate at depth (Figure 4a and b), were almost constant in the flood deposit (Figure 4b). Nitrate was below the detection limit in the new deposit, whereas $\mathrm{Mn}^{2+}$ and $\mathrm{Fe}^{2+}$ started accumulating relatively quickly. Within the thin flood deposit on 29 May, the $\mathrm{Mn}^{2+}$ concentration reached up to $100 \mu \mathrm{M}$, whereas $\mathrm{Fe}^{2+}$ was not detectable (Figure $4 \mathrm{~b}$ ). Ten days later, the $\mathrm{Mn}^{2+}$ concentration increased in the 30-cm thick flood deposit and reached 537 $\mu \mathrm{M}$, and the $\mathrm{Fe}^{2+}$ concentration reached $\sim 900 \mu \mathrm{M}$ below the flood deposit and $500 \mu \mathrm{M}$ just above the former redox front. Sulfides were below the detection limit during all campaigns. Finally, there was a slight decrease in sulfate above the former interface on 8 June.

\subsubsection{Chemical composition of sediment discharged during the Cevenol flood in 2008}

In contrast to the May-June 2008 deposit, the November 2008 flood layer was on average enriched in OC (1.7-2.4\%) with the presence of plant fibers throughout the unit, whereas the IC content was low (3.0-3.4\%). This clear difference is explained by land use in the Rhone watershed, with more forestry and fruit orchards in the Cevennes, and by the timing of the flood in the middle of the fall when most trees have lost their leaves, thus providing large quantities of plant debris. In terms of average $\mathrm{Mn}$ and Fe content, this flood unit was similar to the generalized flood (Table 2). However, the Cevenol deposit was not homogenous over the prodelta area. Some features from the Cevenol deposit were visible in Station AK, but 
not in Station A. The top $5 \mathrm{~cm}$ in Station $\mathrm{AK}$ (Figure 3d) was enriched in $\mathrm{Fe}_{\mathrm{Asc}}$ (up to 100 $\mu \mathrm{mol} \mathrm{g} \mathrm{g}^{-1}$ ), $\mathrm{Fe}_{\mathrm{HCl}}$ (up to $220 \mu \mathrm{mol} \mathrm{g}{ }^{-1}$ ) and $\mathrm{OC}$ (up to $6.8 \%$ ), whereas the layer from 5 to 10 cm depth was only slightly enriched in OC (up to $2.5 \%$ ). In contrast, Station A showed enrichment, with a peak at $5 \mathrm{~cm}$ depth in $\mathrm{OC}(2.3 \%), \mathrm{Fe}_{\mathrm{Asc}}\left(60 \mu \mathrm{mol} \mathrm{g} \mathrm{g}^{-1}\right)$, and $\mathrm{Fe}_{\mathrm{HCl}}(180$ $\mu \mathrm{mol} \mathrm{g}{ }^{-1}$ ) (Figure $4 \mathrm{c}$ ). This heterogeneity can be explained by the lower intensity of the Cevenol flood (solid particle load was 5 times lower than in the generalized flood), which does not lead to a homogeneous coverage of the entire prodelta.

\subsubsection{Porewater chemistry after the Cevenol flood}

High concentrations of DOC (up to $6.1 \mathrm{mM}$ ), $\mathrm{Mn}^{2+}$ (up to $840 \mu \mathrm{M}$ ) and $\mathrm{Fe}^{2+}(>900 \mu \mathrm{M}$ ) were recorded in the Cevenol deposit (Figure 4c). Sulfate decreased from 28 to $12 \mathrm{mM}$ within this $10 \mathrm{~cm}$ layer, sulfides were not detected and DIC increased from 2.2 to $37 \mathrm{mM}$. A peak of $\mathrm{NO}_{3}{ }^{-}$of up to $18 \mu \mathrm{M}$ was measured in the anoxic zone.

\subsection{The continental shelf}

Station C, located in the continental shelf, was not affected by the successive flood events that occurred in 2008 (Figure 5). Therefore, all dissolved and particulate species measured at this station showed the same pattern across all cruises, with similar oxygen fluxes (Cathalot et al., 2010 - Table 3), and comparable ranges of reduced species' concentrations (Figure 5). In general, compared with the prodelta area, concentrations of mineralization products were lower (ammonium $<400 \mu \mathrm{M}$ versus $>3000 \mu \mathrm{M}$ for Station A; DIC $<5 \mathrm{mM}$ versus $>60 \mathrm{mM}$ for Station $\mathrm{A}$ ) and $\mathrm{SO}_{4}{ }^{2-}$ reduction started deeper at weaker rates (Figure 5).

\section{DISCUSSION}

Sediments carried during floods settle exclusively in the prodelta area, with some rare export events further offshore during extreme events (Boudet et al., 2017). The Rhône 
prodelta sediments thus exhibit Especific biogeochemical processes due to higher sedimentation rates (up to $50 \mathrm{~cm} \mathrm{yr}^{-1}$; Charmasson et al., 1998) and higher OC fluxes (Lansard et al., 2009; Cathalot et al., 2010; Pastor et al., 2011b; Rassmann et al., 2016) than in the adjacent continental shelf. Sulfate reduction and reduced element recycling dominate the biogeochemical processes in the prodelta, whereas oxic respiration dominates in the continental shelf (Pastor et al., 2011b).

Our discussion focused on the prodelta area and on the changes in the diagenetic processes occurring over short (days) or long term (weeks to months) in two contrasting flood deposits, mainly in terms of manganese and iron dynamics. Also, we demonstrate how a freshly deposited layer can trigger various transient reactions.

\subsection{Short-term changes (days) of the global porewater chemistry after a generalized flood}

To investigate short-term changes in the porewater chemistry associated with a generalized flood in the prodelta, we made the assumption that the distribution of elements in the sediment porewater at Station A had reached a relative equilibrium in April 2007, 46 days after a weak oceanic flood event (Pastor et al., 2011b; Figure 4a). In April 2007, nitrification had occurred in the oxic layer with $\mathrm{NO}_{3}{ }^{-}$concentrations of up to $12 \mu \mathrm{M}$, and denitrification had occurred below the oxic zone (Pastor et al., 2011b). Reduction of particulate manganese and iron occurred with a concomitant release of $\mathrm{Mn}^{2+}$ and $\mathrm{Fe}^{2+}$ into the sediment porewater. Concentrations reached $\sim 100 \mu \mathrm{M}$ for $\mathrm{Mn}^{2+}$ and $\sim 750 \mu \mathrm{M}$ for $\mathrm{Fe}^{2+}$. Sulfate reduction occurred, illustrated by a sharp decrease in sulfate concentration within the first $20 \mathrm{~cm}$. No sulfide was measured in the sediment porewaters due to its intensive oxidation (Pastor et al., 2011b) into sulfur minerals $\left(\mathrm{S}^{0}, \mathrm{FeS}, \mathrm{FeS}_{2} \ldots\right)$ and/or back to sulfate. Anoxic OC mineralization rates (the sum of manganese oxides, iron oxides and sulfate 
reduction, and assumed stoichiometries of 2:1, 4:1,1:2, respectively) reached $134 \mathrm{mmol} \mathrm{C}$ $\mathrm{m}^{-2} \mathrm{~d}^{-1}$ (Pastor et al., 2011b).

Cathalot et al. (2010) indicated that the oxygen trapped below and within the flood deposit during its deposition was consumed within $3 \mathrm{~h}$. Assuming a peak in nitrate similar to the one measured in April 2007 (12 $\mu \mathrm{M}$; Figure 4a), and an integrated net consumption rate at steady-state before the flood deposit $\left(\sim 0.9 \mu \mathrm{mol} \mathrm{L}^{-1} \mathrm{~h}^{-1}\right)$ calculated using the PROFILE software (Berg et al., 1998), less than $14 \mathrm{~h}$ are required to consume the entire nitrate stock under suboxic conditions below the flood deposit. Given that no nitrate was detected at the end of the flood, we conclude that nitrification rates did not exceed denitrification and that nitrate concentrations had not yet started to build up in the new deposit. $\mathrm{Mn}^{2+}$ and $\mathrm{Fe}^{2+}$ concentrations changed at different rates. Within the thin flood deposit on 29 May 2008, the $\mathrm{Mn}^{2+}$ concentration reached $100 \mu \mathrm{M}$, whereas $\mathrm{Fe}^{2+}$ was not detectable (Figure 4b), suggesting a faster reduction of manganese oxides compared to iron oxides (Aller, 2004, Abril et al., 2010). Ten days later, the $\mathrm{Mn}^{2+}$ concentration increased in the $30-\mathrm{cm}$ thick flood deposit, confirming a continuous reduction of reactive manganese oxides. $\mathrm{Fe}^{2+}$ concentration reached $\sim 900 \mu \mathrm{M}$ below the flood deposit and $500 \mu \mathrm{M}$ just above the former redox front, indicating that iron oxides started to be reduced within 10 days after the flood layer deposition, with a strong link to the former redox front as shown by the peculiar shape of the $\mathrm{Fe}^{2+}$ profile around this boundary (Figure $4 \mathrm{~b}$ ). This temporal succession of electron acceptors has also been observed in other transitory deposits, such as in a highly turbid estuarine zone (Abril et al., 2010), the Saguenay fjord (Deflandre et al., 2002, Mucci et al., 2003), in unconformable shelf sediments (Aller et al., 2004) or in estuarine flood deposits (Thibault de Chanvalon et al., 2016), indicating that, immediately after deposition, sediments are not sufficiently reducing to maintain $\mathrm{Fe}^{2+}$ in solution (Deflandre et al., 2002), 
and additionally that $\mathrm{Fe}^{2+}$ may interact with manganese oxides (Postma, 1985) and potentially with hydrogen sulfide produced in the vicinity of the former redox front. To test the hypothesis of high hydrogen sulfide production, stocks of sulfate were calculated in the sediment located below the former redox front $(6 \mathrm{~cm}$ thickness $)$, at the beginning and at the end of the flood (10-day interval). The stoichiometric ratio for the mineralization of $\mathrm{CH}_{2} \mathrm{O}$ is $0.5 \mathrm{~mol}$ of $\mathrm{SO}_{4}{ }^{2-}$ used to oxidize $1 \mathrm{~mol}$ of carbon, producing $0.5 \mathrm{~mol}$ of hydrogen sulfide. From this stoichiometry, the sulfate reduction rate would be $167 \mathrm{mmol} \mathrm{C} \mathrm{m}^{-2} \mathrm{~d}^{-1}$ below the former redox front. Comparing this estimate with the value calculated for April 2007, including all anoxic processes (134 $\mathrm{mmol} \mathrm{C} \mathrm{m}^{-2} \mathrm{~d}^{-1}$; Pastor et al., 2011b), it seems that sulfate reduction was enhanced just below the deposit. This enhancement may be due to fresh OM buried below the flood deposit (i.e. freshly dead organisms, entrained plankton), leading to significant production of hydrogen sulfide, diffusing and reacting with iron and manganese phases (no sulfide was detected in the porewaters), and thus generating the irregular profile of $\mathrm{Fe}^{2+}$.

To summarize, it appears that the consumption of oxygen and $\mathrm{NO}_{3}{ }^{-}$took only a few hours within the new deposit. Then, $\mathrm{Mn}^{2+}$ concentration started to build up right after the beginning of the flood, whereas the $\mathrm{Fe}^{2+}$ concentration responded only after a few days or weeks. This difference can be attributed to the redox capacity of the sediment, evolving from oxidized, during the flood layer deposition, to more reducing conditions after a few days or weeks, allowing $\mathrm{Fe}^{2+}$ to stabilize in solution. Sulfate reduction was enhanced just below the underlying former redox front due to an input of fresh OM. The resulting high production of $\mathrm{H}_{2} \mathrm{~S}$ probably led to the precipitation of sulfur minerals in close vicinity to the former redox front, prohibiting hydrogen sulfide build-up. 


\subsection{Manganese oxide reduction PTED MANUSCRIPT}

Figure 3 shows the evolution of the flood deposit between May and December 2008. We calculated an average solid-phase concentration within each deposit. Average $\mathrm{Mn}_{\text {Asc }}$ concentrations evidenced a clear oxides reduction over time (Figure $6-\mathrm{R}^{2}=0.96, \mathrm{p}<0.05$ ). From the slope $\left(-0.0085 \mu \mathrm{mol} \mathrm{g} \mathrm{g}^{-1} \mathrm{~d}^{-1}\right)$, we calculated an overall reduction rate of $1.8 \mathrm{mmol}$ $\mathrm{m}^{-2} \mathrm{~d}^{-1}$, using a bulk density of $2.65 \mathrm{~g} \mathrm{~cm}^{-3}$, an average flood deposit thickness of $25 \mathrm{~cm}$ with an average porosity of 0.68 (data not shown). This reduction process was also demonstrated by a good correlation between the $\mathrm{Mn}^{2+}$ and $\mathrm{Mn}_{\text {Asc }}$ concentrations (Figure $7-\mathrm{R}^{2} \sim 0.6-0.8$ ), with a $\mathrm{Mn}^{2+}: \mathrm{Mn}_{\mathrm{Asc}}$ ratio of 25 before the flood and $>55$ in the flood deposit (in $\mu \mathrm{M} \mu \mathrm{mol}^{-1} \mathrm{~g}^{-}$ $1)$.

Within the organic-rich deposit of the November 2008 flood, enrichment in $\mathrm{Mn}^{2+}$ was observed and linked to the peaks in $\mathrm{Mn}_{\mathrm{Asc}}$ and DOC recorded at the same depth. Elevated $\mathrm{Mn}^{2+}$ highlights the high rate of manganese oxide reduction in this flood layer, which may occur through the re-oxidation of hydrogen sulfide by manganese oxides to sulfur and $\mathrm{SO}_{4}{ }^{2-}$, through OM remineralization, or even through ammonium oxidation (see Section 5.5).

Continental margin sediments are known to supply manganese to the shallow ocean water column, through the dissolution of manganese oxides (Johnson et al., 1992; Aller et al., 2004; McManus et al., 2012). No direct measurements of $\mathrm{Mn}^{2+}$ fluxes out of the sediment have been made to date in the studied area. We carried out indirect calculations from porewater profiles using Fick's first law of diffusion on our data, but the resolution was relatively poor and showed large uncertainties. Nevertheless, gradients measured at the top of each $\mathrm{Mn}^{2+}$ profile show substantial differences depending on the history of sedimentation, with a value increasing by at least five fold in December 2008 compared with May 2008 (Figure 4b and c). 
Therefore, the prodelta seems to act as a bioreactor in which reactive manganese oxides are intensively reduced, likely with several reduction/oxidation cycles (e.g. depositionresuspension cycles; Blair and Aller, (2012)) before burial in deeper sediment layers, and/or transport to the continental shelf during storms, for example. Its release into the water column may change with the type of sediments deposited during floods.

\subsection{Iron and phosphorus dynamics}

Unlike $\mathrm{Mn}_{\mathrm{Asc}}$ in the deposit during the 6 months that followed the flood event, $\mathrm{Fe}_{\mathrm{Asc}}$ was not substantially reduced $\left(\mathrm{R}^{2}=0.079\right.$ - graph not shown). This lack of visible reduction is in agreement with the conclusion from Section 5.1 in which we show that reactive manganese oxide reduction started immediately in the flood layer, and iron oxides were reduced primarily below the flood layer, and probably little, if at all, in the flood layer (alternatively, it quickly reprecipitated as authigenic iron phases, extractible with the ascorbate reagent) to contribute to a clear decrease in $\mathrm{Fe}_{\mathrm{Asc}}$ in the solid phase. The value of the $\mathrm{Fe}_{\mathrm{Asc}}: \mathrm{P}_{\mathrm{Asc}}$ ratio of 10 in the preflood sediment (Table 2) is consistent with a saturation of phosphorus adsorbed onto sedimentary iron oxides, as reported in other locations (e.g. Anschutz et al., 1998; 2007), which can be related to the high $\mathrm{PO}_{4}{ }^{3-}$ concentrations in sediment porewaters in the preflood sediments (up to $450 \mu \mathrm{M}$ - data not shown). The high $\mathrm{Fe}_{\mathrm{Asc}}: \mathrm{P}_{\mathrm{Asc}}$ ratio in the flood deposit (with an average of 29; Table 2) suggests that mineralization in the recent deposits does not yet supply enough phosphorus to lower the $\mathrm{Fe}_{\mathrm{Asc}}: \mathrm{P}_{\mathrm{Asc}}$ ratio of iron oxides $\left(\mathrm{PO}_{4}^{3-}\right.$ was not detected in fresh deposits). This $\mathrm{Fe}_{\mathrm{Asc}}: \mathrm{P}_{\mathrm{Asc}}$ ratio decreased over time from $\sim 29 \pm 4$ in June to $17 \pm 5$ in October, concomitant to an increase in $\mathrm{P}_{\mathrm{Asc}}$ concentrations in the flood deposit. This pattern shows the progressive increase in OM mineralization in this unit, with an increase in phosphate release (data not shown), and the progressive adsorption of this phosphate on iron oxides, probably limiting its diffusion into the water column. Iron oxides, 
whether freshly brought by floods=or precipitated in the oxic layer (authigenic phases), buffer the phosphorus release into the water column, as previously observed in other locations (Sundby et al., 1992; Anschutz et al., 1998; Thibaut de Chanvalon et al., 2016).

\subsection{Dissolved organic carbon fluxes}

The new deposit observed in the prodelta area was about $10 \mathrm{~cm}$ thick at the top of the core retrieved at Station A, 26 days after the flood event of November 2008 (Figure 4b). The production rates of DOC and dissolved manganese seemed higher compared with the previous measured profiles at this station. This layer was enriched in OC and plant fibers, and when the $\mathrm{OM}$ is degraded (e.g. hydrolyzed), it produces large quantities of dissolved OM, including DOC. Nevertheless, the final product of OM mineralization is DIC, which did not show the same pattern as DOC in this unit. This divergence in behavior may mean that most of the DOC produced in this layer is refractory and thus not used in the terminal respiration step (Burdige, 2002). Nevertheless, a layer with high accumulation of DOC may support an increased flux of DOC into the water column linked to the OC mineralization rates (Burdige et al., 1999). In the Rhône prodelta, total OC mineralization can reach up to $150 \mathrm{mmol} \mathrm{C} \mathrm{m}^{-2} \mathrm{~d}^{-1}$ (Pastor et al., 2011b), and DOC fluxes can then reach several $\mathrm{mmol} \mathrm{m}^{-2}$ $\mathrm{d}^{-1}$. Comparing the DOC gradient in May 2008 (just below the flood deposit) with the gradient measured in December 2008 shows that this estimate could at least double during events such as this Cevenol flood.

\subsection{Impact on the nitrogen cycle}

A peak in $\mathrm{NO}_{3}{ }^{-}$of up to $18 \mu \mathrm{M}$ was measured in the anoxic zone. With an oxygen penetration depth of $<2 \mathrm{~mm}$ (Table 3), the occurrence of a significant peak in nitrate in the anoxic zone within the organic-rich unit clearly indicates that anoxic nitrification rates exceeded denitrification rates (Figure 4c). Given that the nitrate concentration in the bottom 
waters was $<1 \mu \mathrm{M}$, it is unlikely that the nitrate peak was induced by direct bio-irrigation of bottom waters. Therefore, the production of nitrate in this layer may be due to the anaerobic oxidation of ammonium by manganese oxides as previously reported in various studies (Aller et al., 1998; Hulth et al., 1999; Deflandre et al., 2000, 2002; Anschutz et al., 2000; Hyacinthe et al., 2001; Bartlett et al., 2007, 2008). This type of reaction has implications in terms of nitrogen mobilization, with the oxidation of ammonium to nitrite and nitrate (and/or $\mathrm{N}_{2}$ ), followed by the denitrification process from nitrate to $\mathrm{N}_{2}$ (Hulth et al., 2005).

\section{CONCLUSION}

The Rhône prodelta area receives pulsed inputs of particulate matter though flood events, primarily enriched in manganese oxides and showing varying levels of carbon content. The study of two different flood events (generalized and Cevenol floods) demonstrates that the reduction of manganese oxides is very efficient in this area, regardless of the type of flood. We measured a reactive manganese oxide reduction rate of $1.8 \mathrm{mmol} \mathrm{m}^{-2} \mathrm{~d}^{-1}$ during the 6 months following the generalized flood event, and highlighted that the outflux of manganese in the water column can be enhanced depending on the composition of the sediments carried by floods. After a significant flood deposition of several centimeters, the redox capacity of the sediment inhibits the build-up of $\mathrm{Fe}^{2+}$ in porewater through the reduction of iron oxides, until the sediment is reduced enough to allow $\mathrm{Fe}^{2+}$ to accumulate. These iron oxides also buffer the release of phosphorus through phosphate adsorption on these mineral phases. Although anoxic processes, and especially sulfate reduction, dominate OM mineralization in this area, no dissolved sulfide was measured, indicating that it is reoxidized by manganese or/and iron oxides or precipitates with $\mathrm{Fe}^{2+}$. These episodic pulsed inputs of sediments supply the area with enough oxides to completely inhibit any 
accumulation of free sulfide in the porewater. Pulsed accumulation of sediment can also trigger transient processes such as anaerobic oxidation of ammonium, illustrated in the Cevenol flood layer by a high nitrate accumulation in the anoxic layer. We did not investigate the anaerobic oxidation of ammonium in this study; further research is required to better constrain the impact on nitrogen cycling.

\section{ACKNOWLEDGEMENTS}

We would like to thank the captain and crew members of the RV Tethys II (CNRS-INSU) and the entire scientific crew for their technical assistance during sample collection and handling especially Bruno Bombled, Cécile Cathalot and Roselyne Buscail. We thank Mireille Arnaud and Frédérique Eyrolle from the French National Research Agency (ANR) EXTREMA project (contract ANR-06-VULN-005) for providing samples. We thank Amaury Gaillard, Laure Sandoval, Hassiba Lazar and Céline Charbonnier for analytical assistance. We also thank the three reviewers for their helpful comments on the manuscript. Discharge and TSM data were provided by the CNR and the SORA as part of an agreement with IRSN in the ANR EXTREMA project. This work was funded by the ANR program CHACCRA (contract number ANR-VULN-06-001-01), the French INSU-EC2CO program RiOMar.fr, and a grant from AMORAD (ANR-11-RSNR-0002).

\section{REFERENCES}

Abril, G., Commarieu, M. V., Etcheber, H., Deborde, J., Deflandre, B., Zivadinovic, M. K., Chaillou, G., and Anschutz, P.(2010). In vitro simulation of oxic/suboxic diagenesis in an estuarine fluid mud subjected to redox oscillations. Estuarine Coastal and Shelf Science. 88: 279-291.

Aller, R. C. (1998). Mobile deltaic and continental shelf muds as suboxic, fluidized bed reactors. Marine Chemistry 61: 143-155. 
Aller, R. C., Hall, P.O.J., Rude,P.D., and Aller, J.Y. (1998). Biogeochemical heterogeneity and suboxic diagenesis in hemipelagic sediments of the Panama Basin. Deep-Sea Research I 45: 133-165.

Aller, R. C. (2004). Conceptual models of early diagenetic processes: The muddy seafloor as an unsteady, batch reactor. Journal of Marine Research. 62: 815-835.

Aller, R. C., Heilbrun, C., Panzeca, C., Zhu, Z., and Baltzer, F. (2004). Coupling between sedimentary dynamics, early diagenetic processes, and biogeochemical cycling in the Amazon-Guianas mobile mud belt: coastal French Guiana. Marine Geology. 208: 331-360.

Aller, R. C., Madrid, V., Chistoserdov, A., Aller, J. Y., and Heilbrun, C. (2010). Unsteady diagenetic processes and sulfur biogeochemistry in tropical deltaic muds: Implications for oceanic isotope cycles and the sedimentary record. Geochimica Et Cosmochimica Acta. 74: 4671-4692.

Allison, M. A., Lee, M.T., Ogston, A.S., Aller R.C. (2000). Origin of Amazon mudbanks along the northeastern coast of South America. Marine Geology 163: 241-256.

Anschutz P., Z. S., Sundby B., Mucci A., and Gobeil C. (1998). Burial efficiency of phosphorus and the geochemistry of iron in continental margin sediments. Limnology and Oceanography 43(1): 53-64.

Anschutz, P., Sundby, B., Lefrançois, L., Luther III, G.W., and Mucci, A. (2000). Interactions between metal oxides and species of nitrogen and iodine in bioturbated marine sediments. Geochimica et Cosmochimica Acta 64(16): 2751-2763.

Anschutz, P., Dedieu, K., Desmazes, F., and Chaillou, G. (2005). Speciation, oxidation state, and reactivity of particulate manganese in marine sediments. Chemical Geology 218(3-4): 265-279.

Anschutz, P., Chaillou, G., and Lecroart, P. (2007). Phosphorus diagenesis in sediment of the Thau Lagoon. Estuarine, Coastal and Shelf Science 72(3): 447-456.

Antonelli, C., Eyrolle, F., Rolland, B., Provansal, M., and Sabatier, F. (2008). Suspended sediment and ${ }^{137}$ Cs fluxes during the exceptional December 2003 flood in the Rhone River, Southeast France. Geomorphology 95(3-4): 350-360.

Antonelli, C., Provansal, M., and Vella, C. (2004). Recent morphological channel changes in a deltaïc environment. The case of the Rhône River, France. Geomorphology 57: 385-402.

Arnosti, C., and Holmer, M. (2003). Carbon cycling in a continental margin sediment: contrasts between organic matter characteristics and remineralization rates and pathways. Estuarine, Coastal and Shelf Science 58: 197-208.

Bartlett, R., Mortimer, R. J. G., and Morris, K. (2007). Anoxic nitrification: Evidence from Humber Estuary sediments (UK). Chemical Geology 250(1-4): 29-39. 
Bartlett, R., Mortimer, R. J. G., and Morris, K. (2008).Anoxic nitrification: Evidence from Humber Estuary sediments (UK). Chemical Geology 250: 29-39.

Berg, P., Risgaard-Petersen, N., and Rysgaard, S. (1998). "nterpretation of measured concentration profiles in sediment pore water. Limnology and Oceanography 43(7): 1500-1510.

Blair, N. E., and Aller, R. C. (2012). The Fate of Terrestrial Organic Carbon in the Marine Environment. Annual Review of Marine Science. 4: 401-423.

Bonifacio, P., et al. (2014). Spatiotemporal changes in surface sediment characteristics and benthic macrofauna composition off the Rhone River in relation to its hydrological regime. Estuarine Coastal and Shelf Science 151: 196-209.

Boudet, L., Sabatier, F and Radakovitch, O. (2017). Modelling of sediment transport pattern in the mouth of the Rhone delta: Role of storm and flood events. Estuarine, Coastal and Shelf Science. 198: 568-582.

Bourrin, F., and Durrieu de Madron, X. (2006). Contribution to the study of coastal rivers and associated prodeltas to sediment supply in Gulf of Lions (NW Mediterranean Sea). Vie et Milieu - Life and Environment 56(4): 307-314.

Bourrin, F., Friend, P. L., Amos, C. L., Manca, E., Ulses, C., Palanques, A., Durrieu de Madron, X., and Thompson, C. E. L. (2008). Sediment dispersal from a typical Mediterranean flood: The Têt River, Gulf of Lions. Continental Shelf Research 28(15): 1895-1910.

Burdige, D. J. (2002). Sediment Pore Waters. Biogeochemistry of Marine Dissolved Organic Matter. C.A. Carlson. D.A. Hansell, Academic Press: 535-577.

Burdige, D. J., Berelson, W.M., Coale, K.H., McManus, J., and Johnson, K.SK (1999). Fluxes of dissolved organic carbon from California continental margin sediments. Geochimica et Cosmochimica Acta. 63: 1507-1515.

Calmet, D., and Fernandez, J.-M. (1990). Caesium distribution in the northwest Mediterranean seawater, suspended particles and sediments. Continental Shelf Research 10: 895-913.

Campbell, S. J., and McKenzie, S.J. (2004). Food related loss and recovery of intertidal seagrass meadows in southern Queensland, Australia. Estuarine, Coastal and Shelf Science 60: 477-490.

Cathalot, C., Rabouille, C., Pastor, L., Deflandre,B., Viollier, E., Buscail, R., Grémare, A., Treignier, C., and Pruski, A. (2010). Temporal variability of carbon recycling in coastal sediments influenced by rivers: assessing the impact of flood inputs in the Rhône River prodelta. Biogeosciences 7: 1187-1205.

Cathalot, C., Rabouille, C., Tisnerat-Laborde, N., Toussaint, F., Kerherve, P., Buscail, R., Loftis, K., Sun, M.Y., Tronczynski, J., Azoury, S., Lansard, B., Treignier, C., Pastor, L. and Tesi, T. (2013) The fate of river organic carbon in coastal areas: A study in the 
Rhone River delta using mültiple isotopic (delta C-13, Delta C-14) and organic tracers. Geochimicaet Cosmochimica Acta 118, 33-55.

Chaillou, G., Anschutz, P., Dubrulle, C., and Lecroart, P. (2007). Transient States in Diagenesis Following the Deposition of a Gravity Layer: Dynamics of $\mathrm{O}_{2}, \mathrm{Mn}, \mathrm{Fe}$ and N-Species in Experimental Units. Aquatic Geochemistry 13: 157-172.

Charmasson, S., Bouisset, P., Radakovitch, O., Pruchon, A.-S., and Arnaud, M. (1998). Long-core profiles of $137 \mathrm{Cs}, 134 \mathrm{Cs}, 60 \mathrm{Co}$, and $210 \mathrm{~Pb}$ in sediment near the Rhône River (Northwestern Mediterranean sea). Estuaries 21: 367-378.

Cline, J. D. (1969). Spectrophotometric determination of hydrogen sulphide in natural waters. Limnology and Oceanography 14: 454-458.

Deborde, J., Anschutz, P., Chaillou, G., Etcheber, H., Commarieu, M.V., Lecroart, P., Abril, G. (2007). The dynamics of phosphorus in turbid estuarine systems: Example of the Gironde estuary (France). Limnology and Oceanography 52(2): 862-872.

Deflandre, B., Gagné, J.-P., Sundby, B., Mucci, A., Guignard, C., and Anschutz, P. (2000). The 1996 flood event: disruption of the ongoing diagenesis of Saguenay Fjord sediments. Proc. Can. Geotech. Soc. 1: 117-122.

Deflandre, B., Mucci, A., Gagné, J-P., Guignard, C., and Sundby, B. (2002). Early diagenetic processes in coastal marine sediments disturbed by a catastrophic sedimentation event. Geochimica et Cosmochimica Acta 66(14): 2547-2558.

Dufois, F., Verney, R., Le Hir, P., Dumas, F., and Charmasson, S. (2014). Impact of winter storms on sediment erosion in the Rhone River prodelta and fate of sediment in the Gulf of Lions (North Western Mediterranean Sea). Continental Shelf Research 72: $57-72$.

Durrieu de Madron, X., Abassi, A., Heussner, S., Monaco, A., Aloisi, J.-C., Radakovitch, O., Giresse, P., Buscail, R., and Kerherve, P. (2000). Particulate matter and organic carbon budgets for the Gulf of Lion (NW Mediterranean). Oceanologica Acta 23(6): 717-730.

Eyrolle, F., Radakovitch, O., Raimbault, P., Charmasson, S., Antonelli, C., Ferrand, E., Aubert, D., Raccasi, G., Jacquet, S. and Gurriaran, R. (2012) Consequences of hydrological events on the delivery of suspended sediment and associated radionuclides from the Rhône River to the Mediterranean Sea. J. Soils Sediments. 12 (9): 1479-1495

Fagervold, S.K., Bourgeois, S., Prusky, A.M., Charles, F., Kerhervé, P., Vétion, G., Galand, P.E. (2014). River organic matter shapes microbial communities in the sediment of the Rhône prodelta. The ISME journal. 1-12

Froelich, P. N., Klinkhammer, G.P., Bender, M.L., Luedtke, N.A., Heath, G.R., Cullen, D., Dauphin, P., Hammond, D., Hartman, B., and Maynard, V. (1979). Early oxidation of organic matter in pelagic sediments of the eastern equatorial Atlantic: suboxic diagenesis. Geochimica et Cosmochimica Acta 43: 1075-1090. 
Grasshoff, K., Johannsen, H. (1972). A new sensitive and direct method for the automatic determination of ammonia in sea water. J. Cons. Int. Explor. Mer. 34: 516-521.

Grasshoff, K., Ehrhardt, M., and Kremling, K., (1983). Methods of Seawater Analysis. Verlag Chemie, Basel: 1-19.

Hall, P. O. J., and Aller, R.C (1992). Rapid, small-volume, flow injection analysis for $\Sigma \mathrm{CO}_{2}$ and $\mathrm{NH}_{4}{ }^{+}$in marine and freshwaters. . Limnology and Oceanography 37(5): 11131119 .

Hastings, R. H., Goñi, M. A., Wheatcroft, R. A., and Borgeld, J. C. (2012). A terrestrial organic matter depocenter on a high-energy margin: The Umpqua River system, Oregon. Continental Shelf Research. 39-40: 78-91.

Hulth, S., Aller, R.C., and Gilbert, F. (1999). Coupled anoxic nitrification/manganese reduction in marine sediments. Geochimica et Cosmochimica Acta 63: 49-66.

Hulth, S., Aller, R. C., Canfield, D. E., Dalsgaard, T., Engström, P., Gilbert, F., Sundbäck, K., and Thamdrup, B. (2005). Nitrogen removal in marine environments: recent findings and future research challenges. Marine Chemistry. 94: 125-145.

Hyacinthe, C., Anschutz, P., Carbonel, P., Jouanneau, J. M., and Jorissen, F. J. (2001). Early diagenetic processes in the muddy sediments of the Bay of Biscay. Marine Geology 177(12): 111-128.

Johnson, K. S., Berelson, W. M., Coale, K. H., Coley, T. L., Elrod, V. A., Fairey, W. R., Iams, H. D., Kilgore, T. E., and Nowicki, J. L. (1992). Manganese flux from continental margin sediments in a transect through the oxygen minimum. Science. 257: $1242-1245$.

Koroleff, F. (1969). Direct determination of ammonia in natural waters as indo-phenol blue. International Council for the Exploration of the Sea: 9-22.

Kostka, J. E., and Luther III, G.W. (1994). Partitioning and speciation of solid phase iron in saltmarsh sediments. Geochimica et Cosmochimica Acta 58: 1701-1710.

Lansard, B., Rabouille, C., Denis, L. and Grenz, C. (2009) Benthic remineralization at the land-ocean interface: A case study of the Rhone River (NW Mediterranean Sea). Estuarine Coastal and Shelf Science 81, 544-554.

Leithold, E. L. and Hope, R. S. (1999). Deposition and modification of a flood layer on the northern California shelf: lessons from and about the fate of terrestrial particulate organic carbon. Marine Geology. 154: 183-195.

Lin, H. and M. Taillefert (2014). Key geochemical factors regulating $\mathrm{Mn}(\mathrm{IV})$-catalyzed anaerobic nitrification in coastal marine sediments. Geochimica et Cosmochimica Acta 133: 17-33.

Marsset, T., and Bellec, V. (2002). Late Pleistocene-Holocene deposits of the Rhône inner continental shelf (France): detailed mapping and correlation with previous continental and marine studies. Sedimentology 49: 255-276. 
McManus, J., Berelson, W. M., Severmann, S., Johnson, K. S., Hammond, D. E., Roy, M., and Coale, K. H (2012). Benthic manganese fluxes along the Oregon-California continental shelf and slope. Continental Shelf Research. 43: 71-85.

Miralles, J., Radakovitch, O. and Aloisi, J.C. (2005) $210 \mathrm{~Pb}$ sedimentation rates from the Northwestern Mediterranean margin. Mar. Geol. 216, 155-167.

Miralles, J., Arnaud, M., Radakovitch, O., Marion, C., and Cagnat, X. (2006). Radionucleide deposition in the Rhône River Prodelta (NW Mediterranean sea) in response to the December 2003 extreme flood. Marine Geology 234: 179-189.

Miserocchi, S., Langone, L., and Tesi, T. (2007). Content and isotopic composition of organic carbon within a flood layer in the Po River prodelta (Adriatic Sea). Continental Shelf Research 27(3-4): 338-358.

Monaco, A., Durrieu de Madron, X., Radakovitch, O., Heussner, S., and Carbonne, J. (1999). Origin and variability of downward biogeochemistry fluxes on the Rhône continental margin (NW Mediterranean). deep-Sea Research I 46: 1483-1511.

Mucci, A., Sundby, B., Gehlen, M., Arakaki, T., Zhong, S., and Silverberg, N. (2000). The fate of organic carbon in continental shelf sediments of eastern Canada: a case study. Deep-Sea Research II 47: 733-760.

Mucci, A., Boudreau, B., and Guignard, C. (2003). Diagenetic mobility of trace elements in sediments covered by a flash flood deposit: Mn, Fe and As. Applied Geochemistry 18: 1011-1026.

Mucci, A., Bernier, G., and Guignard, C.(2015). Mercury remobilization in Saguenay Fjord (Quebec, Canada) sediments: Insights following a mass-flow event and its capping efficiency. Applied Geochemistry 54: 13-26.

Murphy, J., and Riley, J.P. (1962). A modified single solution method for the determination of phosphate in natural waters. Analytica chimica acta 27(C): 31-36.

Nittrouer, C. A. and Sternberg, R. W. (1981). The formation of sedimentary strata in an allochthonous shelf environment - The Washington continental-shelf. Marine Geology. 42: 201-232.

Ollivier, P., Hamelin, B., and Radakovitch, O. (2010). Seasonal variations of physical and chemical erosion: A three-year survey of the Rhone River (France). Geochimica Et Cosmochimica Acta 74(3): 907-927.

Palinkas, C. M., Nittrouer, C.A., Wheatcroft, R.A., and Langone, L. (2005). The use of 7Be to identify event and seasonal sedimentation near the Po River delta, Adriatic Sea. Marine Geology 222-223: 95-112.

Pastor, L., Deflandre, B., Viollier, E., Cathalot, C., Metzger, E.,Rabouille, C., Escoubeyrou, K., Lloret, E., Pruski, A., Vétion, G., Desmalades, M., Buscail, R., and Grémare, A. (2011). Influence of the organic matter composition on benthic oxygen demand in the rhône River prodelta (NW Mediterranean Sea). Continental Shelf Research 31: 10081019 . 
Pastor, L., Cathalot, C., Deflandre, B., Viollier, 'E., Soetaert, K., Ulses, C.,Metzger, E., and Rabouille, C. (2011b). Modeling the biogeochemical processes in sediments from the Rhône River prodelta area (NW Mediterranean Sea). Biogeosciences 8: 1351-1366.

Pelletier, E., Deflandre, B., Nozais, C., Tita, G., Desrosiers, G., Gagné, J.-P., and Mucci, A. (1999). Crue éclair de juillet 1996 dans la région du Saguenay (Quebec). 2. Impacts sur les sédiments et le biote de la baie des Ha! Ha! et du fjord du Saguenay. Canadian Journal of Fisheries and Aquatic Sciences 56: 2136-2147.

Peterson, C. H. (1985). Patterns of lagoonal bivalve mortality after heavy sedimentation and their paleoecological significance. Paleobiology 11: 139-153.

Pont, D., Simonnet, J.P., and Walter, A.V. (2002). Medium-term changes in suspended sediment delivery to the ocean : Consequences of catchment heterogeneity and river management (Rhône River, France). Estuarine, Coastal and Shelf Science 54(1): 118.

Postma D. (1985) Concentration of Mn and separation from Fe in sediments-I. Kinetics and stoichiometry of the reaction between birnessite and dissolved $\mathrm{Fe}(\mathrm{II})$ at $10^{\circ} \mathrm{C}$. Geochim. Cosmochim. Acta 49, 1023-1033.

Radakovitch, O., Charmasson, S., Arnaud, M., and Bouisset, P. (1999). 210Pb and caesium accumulation in the Rhône delta sediment. Estuarine, Coastal and Shelf Science 48: 77-99.

Raiswell R., Canfield D. E., and Berner R. A. (1994) A comparison of iron extraction methods for the determination of degree of pyritisation and the recognition of ironlimited pyrite formation. Chem. Geol. 111, 101-110.

Rassmann, J., Lansard, B., Pozzato, L. and Rabouille, C. (2016) Carbonate chemistry in sediment pore waters of the Rhône River delta driven by early diagenesis (NW Mediterranean). Biogeosc. 13, 5379-5394.

Soetaert, K., Petzoldt, T., and Meysman, F. (2010) MARELAC: tools for aquatic science. R package version 2.1.2 Software.

Sundby B., Gobeil, C., Silverberg, N., and Mucci, A. (1992). The phosphorus cycle in coastal marine sediments. Limnology and Oceanography. 37: 1129-1145.

Tabatabai, M. A. (1974). A rapid method for determination of sulfate in water samples. Environmental Letters 7(3): 237-243.

Tesi, T., Miserocchi, S., Acri, F., Langone, T., Boldrin, A., Hatten, J.A., Albertazzi, S. (2013) Flood-driven transport of sediment, particulate organic matter, and nutrients from the Po River watershed to the Mediterranean Sea. Journal of Hydrology 498: 144-152. 
Tesi, T., Langone, T., Goni, M.A.,WWheateroft, R.A., Miserocchi, S., and Bertasi, F. (2012). Early diagenesis of recently deposited organic matter: A 9-yr time-series study of a flood deposit. Geochimica et Cosmochimica Acta 83: 19-36.

Tesi, T., Langone, T., Goni, M.A., Miserocchi, S., and Bertasi, F. (2008). Changes in the composition of organic matter from prodeltaic sediments after a large flood event (Po River, Italy). Geochimica et Cosmochimica Acta 72: 2100-2114.

Thibault de Chanvalon, A., Mouret, A., Knoery, J., Geslin, E., Peron, O., and Metzger, E. (2016). Manganese, iron and phosphorus cycling in an estuarine mudflat, Loire, France. Journal of Sea Research. 118: 92-102.

Thrush, S. F., Hewitt, J.E., Norkko, A., Cummings, V.J., and Funnell, G.A. (2003). Macrobenthic recovery processes following catastrophic sedimentation on estuarine sandflats. Ecological Applications 13: 1433-1455.

Turk, T. R., and Risk, M.J. (1981). Effect of sedimentation on infaunal invertebrate populations of Cobequid Bay, Bay of Fundy. Canadian Journal of Fisheries and Aquatic Science 38: 642-648.

Van Cappellen, P. and Wang, Y. (1996) Cycling of iron and manganese in surface sediments: a general theory for the coupled transport and reaction of carbon, oxygen, nitrogen, sulfur, iron and manganese. Amer. J. Sci. 296, 197-243.

Viollier, E., Inglett, P. W., Hunter, K., Roychoudhury, A. N., and Van Cappellen, P. (2000). The ferrozine method revisited: $\mathrm{Fe}(\mathrm{II}) / \mathrm{Fe}(\mathrm{III})$ determination in natural waters. Applied Geochemistry 15(6): 785-790.

Wheatcroft, R. A., and Drake, D.E. (2003). Post-depositional alteration and preservation of sedimentary event layers on continental margins, I. The role of episodic sedimentation. Marine Geology. 199: 123-137.

Wheatcroft, R. A., Goñi, M. A., Hatten, J. A., Pasternack, G. B., and Warrick, J. A.. (2010). The role of effective discharge in the ocean delivery of particulate organic carbon by small, mountainous river systems. Limnology and Oceanography. 55: 161-171.

Wu, J., Rabouille, C., Charmasson, S., Reyss, J.L., Cagnat, X. (2018). Constraining the origin of recently deposited particles using natural radionuclides 7Be and 234Thex in deltaic sediments. Continental Shelf Research.

Zebracki, M., F. Eyrolle-Boyer, O. Evrard, D. Claval, B. Mourier, S. Gairoard, X. Cagnat and C. Antonelli (2015). Tracing the origin of suspended sediment in a large Mediterranean river by combining continuous river monitoring and measurement of artificial and natural radionuclides. Science of the Total Environment 502: 122-132. 
Figure 1 Locations of sampling sites. The prodelta is an area within $3 \mathrm{~km}$ of the Rhône River outlet with water depths of $<60 \mathrm{~m}$. Stations A and AK are located inside the prodelta, whereas Station $C$ is located in the adjacent continental shelf.

Figure 2 Rhône (a), Isère (b) and (c) Durance river daily discharge and Rhône Total Suspended Material (TSM) fluxes (d) during the 2007-2009 period. 1-5 numbers stand for the different sampling periods (1=April 2007, 2=June 2008, 3=September 2008, 4=October 2008, 5=December 2008). Sampling dates for stations A, AK and C are indicated by dots. Discharge and suspended material data for the Rhône River have been achieved courtesy of the CNR and the SORA in the framework of a convention with IRSN in the EXTREMA ANR project.

Figure 3 Stratigraphic sequences (modified from Cathalot et al., 2010) along with profiles of organic carbon (OC), inorganic carbon (IC), particulate manganese, iron, and phosphorus (extracted with $\mathrm{HCl}$ and ascorbate (Asc) solution) at station $\mathrm{AK}$ on different days (a,b,c,d). The striped unit represents the flood deposit observed within the sediment column. The dotted unit represents the flood deposit from the November flood event.

Figure 4 Vertical profiles of organic (OC) and inorganic carbon (IC), nitrate $\left(\mathrm{NO}_{3}{ }^{-}\right)$, ammonium $\left(\mathrm{NH}_{4}^{+}\right)$, dissolved manganese and iron $\left(\mathrm{Mn}^{2+}\right.$ and $\left.\mathrm{Fe}^{2+}\right)$, particulate manganese $(\mathrm{Mn})$ and iron $(\mathrm{Fe})$ (extracted with $\mathrm{HCl}$ and an ascorbate (Asc) solution), sulfate $\left(\mathrm{SO}_{4}{ }^{2-}\right)$, dissolved inorganic carbon (DIC) and dissolved organic carbon (DOC) in porewater and sediments from station A on different days $(\mathrm{a}, \mathrm{b}, \mathrm{c})$. The upper $2-5 \mathrm{~cm}$ of the core retrieved on 8 June was lost during recovery and thus not sampled. The striped unit represents the observed May-June 2008 flood deposit. The dotted unit represents the potential flood deposit from the November 2008 flood event.

Figure 5 Vertical profiles of organic carbon (OC), nitrate $\left(\mathrm{NO}_{3}{ }^{-}\right)$, ammonium $\left(\mathrm{NH}_{4}{ }^{+}\right)$, dissolved manganese and iron $\left(\mathrm{Mn}^{2+}\right.$ and $\left.\mathrm{Fe}^{2+}\right)$, particulate manganese $(\mathrm{Mn})$ and iron $(\mathrm{Fe})$ (extracted with $\mathrm{HCl}$ and an ascorbate (Asc) solution), sulfate $\left(\mathrm{SO}_{4}{ }^{2-}\right)$ and dissolved inorganic carbon (DIC) in porewater and sediments at station $\mathrm{C}$ on different days $(\mathrm{a}, \mathrm{b}, \mathrm{c})$. 
Figure 6 Changes in the average labile particulate manganese $\left(\mathrm{Mn}_{\mathrm{Asc}}\right)$ content within the June 2008 flood deposits (black circles) during the 180 days after the flood event. The cross represents the value in the preflood sediment.

Figure 7 Dissolved manganese $\left(\mathrm{Mn}^{2+}\right)$ as a function of labile particulate manganese $\left(\mathrm{Mn}_{\mathrm{Asc}}\right)$ in preflood sediments (pink) and flood sediments (green) at Stations A (triangles), AK45 (diamonds) and C (circles) during the April 2007 and June 2008 cruises. Linear correlations were calculated for values in sediments not affected by the flood $\left(\mathrm{R}^{2}=0.8188\right)$, and for flood sediments at Station AK45 $\left(\mathrm{R}^{2}=0.5918\right)$ and Station A $\left(\mathrm{R}^{2}=0.6228\right)$. 
Table 1: Cruises and location of sampling sites. Stations $A$ and $A K$ are located in the prodelta. Station C is located in the adjacent continental shelf.

\begin{tabular}{|c|c|c|c|c|c|c|c|c|}
\hline Cruise & $\begin{array}{c}\text { Statio } \\
\mathbf{n}\end{array}$ & $\begin{array}{l}\text { Samplin } \\
\text { g date }\end{array}$ & $\begin{array}{c}\text { Rhôn } \\
\text { e } \\
\text { River } \\
\text { water } \\
\text { flow } \\
\left(\mathbf{m}^{3} \mathbf{s}^{-}\right. \\
\left.\mathbf{1}^{-}\right)\end{array}$ & $\begin{array}{c}\text { Rhôn } \\
\text { e } \\
\text { River } \\
\text { TSM } \\
\text { flux } \\
\left(\mathbf{k g ~ m}^{-}\right. \\
\left.{ }_{\mathbf{d}}^{\mathbf{d}^{-1}}\right)\end{array}$ & $\begin{array}{c}\text { Description } \\
\text { of the top } \\
\text { core }\end{array}$ & Lat. $\left({ }^{\circ} \mathbf{N}\right)$ & $\begin{array}{l}\text { Long. } \\
\left({ }^{\circ} \mathbf{E}\right)\end{array}$ & $\begin{array}{c}\text { Wate } \\
\mathbf{r} \\
\text { depth } \\
\text { (m) }\end{array}$ \\
\hline \multirow[b]{2}{*}{$\begin{array}{c}\text { April } \\
2007\end{array}$} & A & 20 April & 788 & 0.35 & / & $\begin{array}{c}43^{\circ} 18.75 \\
1\end{array}$ & $\begin{array}{c}4^{\circ} 51.09 \\
9\end{array}$ & 24 \\
\hline & $\mathrm{C}$ & 23 April & 643 & 0.38 & / & $\begin{array}{c}43^{\circ} 16.40 \\
6\end{array}$ & $\begin{array}{c}4^{\circ} 46.63 \\
7\end{array}$ & 76 \\
\hline \multirow{3}{*}{$\begin{array}{c}\text { May-June } \\
2008\end{array}$} & A & 29 May & 2886 & 153 & $\begin{array}{l}2.5 \mathrm{~cm} \text { gray } \\
\text { mud } \\
31.5 \mathrm{~cm} \\
\text { gray mud }\end{array}$ & $\begin{array}{c}43^{\circ} 18.73 \\
7\end{array}$ & $\begin{array}{c}4^{\circ} 51.10 \\
3 \\
4^{\circ} 51.10 \\
7\end{array}$ & 22 \\
\hline & $\mathrm{C}$ & 30 May & 3821 & 304 & nd & $\begin{array}{c}43^{\circ} 16.45 \\
1\end{array}$ & $\begin{array}{c}4^{\circ} 46.52 \\
4\end{array}$ & 75 \\
\hline & $\mathrm{AK}$ & 8 June & 2886 & 200 & $\begin{array}{c}25 \text { cm gray } \\
\text { mud }\end{array}$ & $\begin{array}{c}43^{\circ} 18.42 \\
7\end{array}$ & $\begin{array}{c}4^{\circ} 51.31 \\
6\end{array}$ & 42 \\
\hline $\begin{array}{l}\text { Septembe } \\
\text { r } 2008\end{array}$ & $\mathrm{AK}$ & $6 \mathrm{Sept}$ & 2432 & 56 & nd & $\begin{array}{c}43^{\circ} 18.42 \\
0\end{array}$ & $\begin{array}{c}4^{\circ} 51.08 \\
0\end{array}$ & 43 \\
\hline $\begin{array}{c}\text { October } \\
2008\end{array}$ & $\mathrm{AK}$ & $16 \mathrm{Oct}$ & 695 & 0.38 & nd & $\begin{array}{c}43^{\circ} 18.42 \\
0\end{array}$ & $\begin{array}{c}4^{\circ} 51.30 \\
0\end{array}$ & 46 \\
\hline $\begin{array}{c}\text { December } \\
2008\end{array}$ & $\mathrm{~A}$ & $4 \mathrm{Dec}$ & 1436 & 2 & New & $43^{\circ} 18.79$ & $4^{\circ} 51.32$ & 21 \\
\hline
\end{tabular}


s deposit

rich in

organic

fibers

$43^{\circ} 16.34 \quad 4^{\circ} 46.19$

$\begin{array}{llllll}\mathrm{C} & 4 \mathrm{Dec} & 1436 & 2 & \text { nd } & 0\end{array}$

New

heterogenou

s deposit $\quad 43^{\circ} 18.41 \quad 4^{\circ} 51.37$

AK $\quad 4$ Dec $1436 \quad 2$

rich in 8

organic

fibers

TSM: total suspended matter; nd: no data

Table 2: Characteristics of the sediment solid phase in the prodelta. Before the May-June 2008 flood event, all values are averages of several cores except the total suspended matter (TSM) sample which is only one sample.

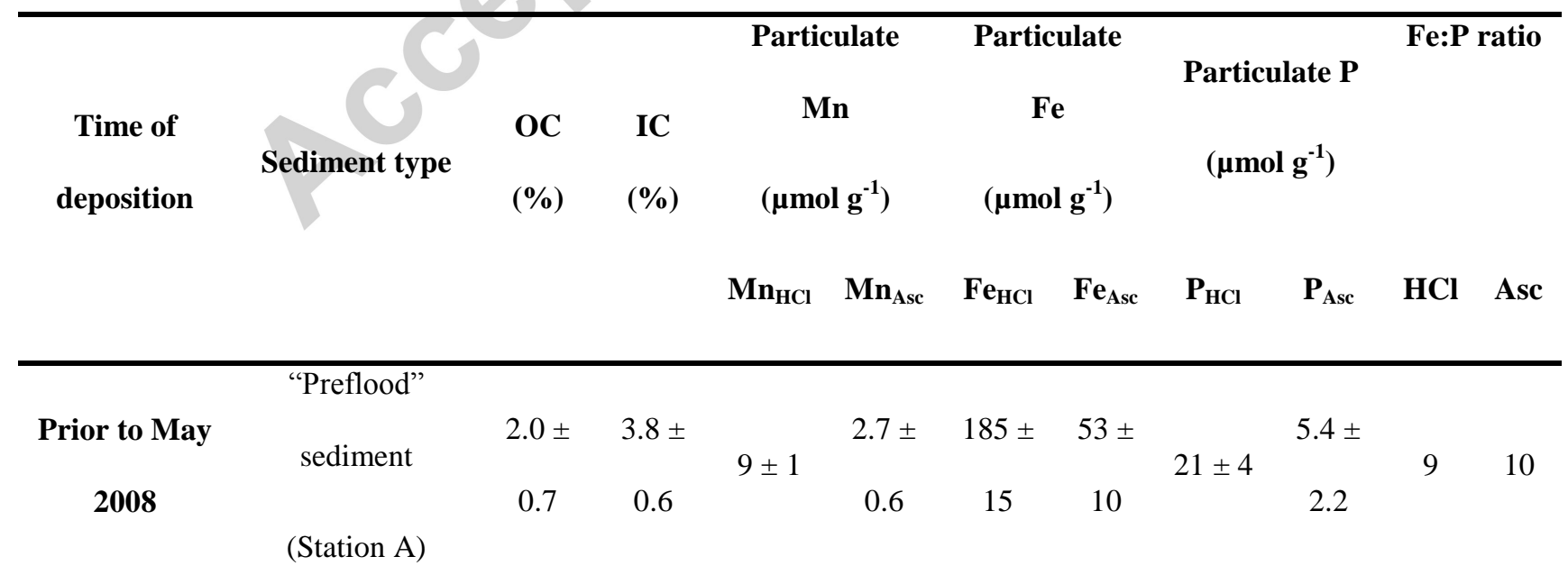

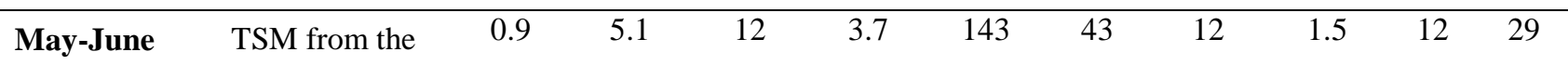




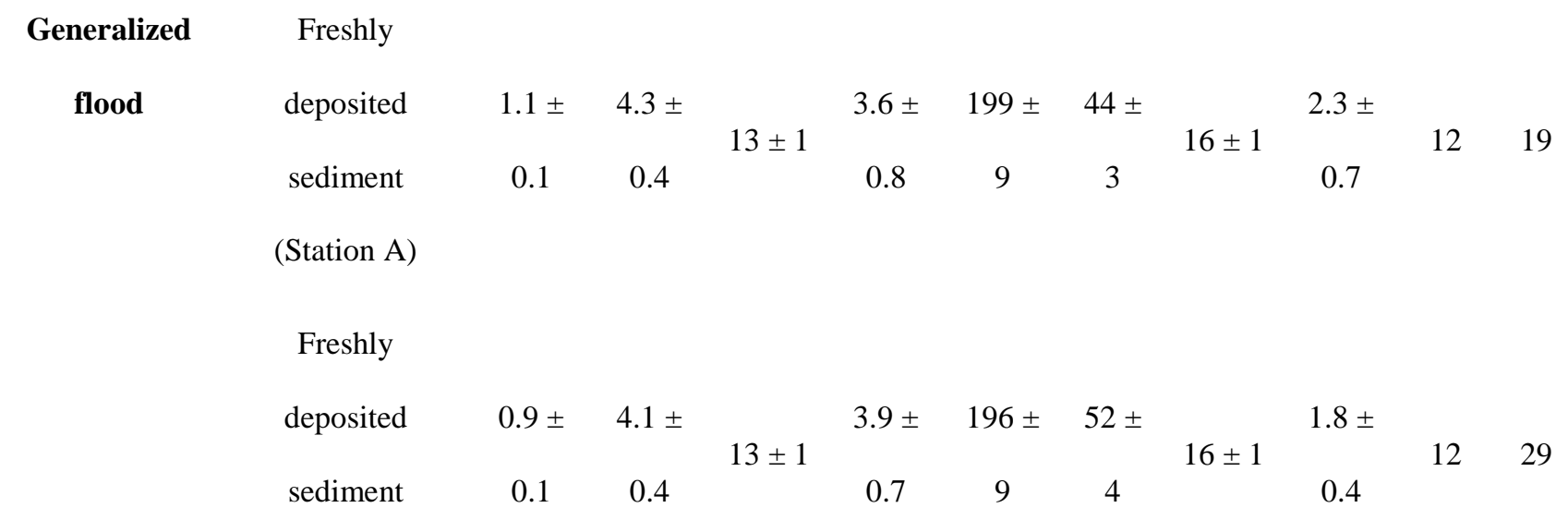

(Station AK)

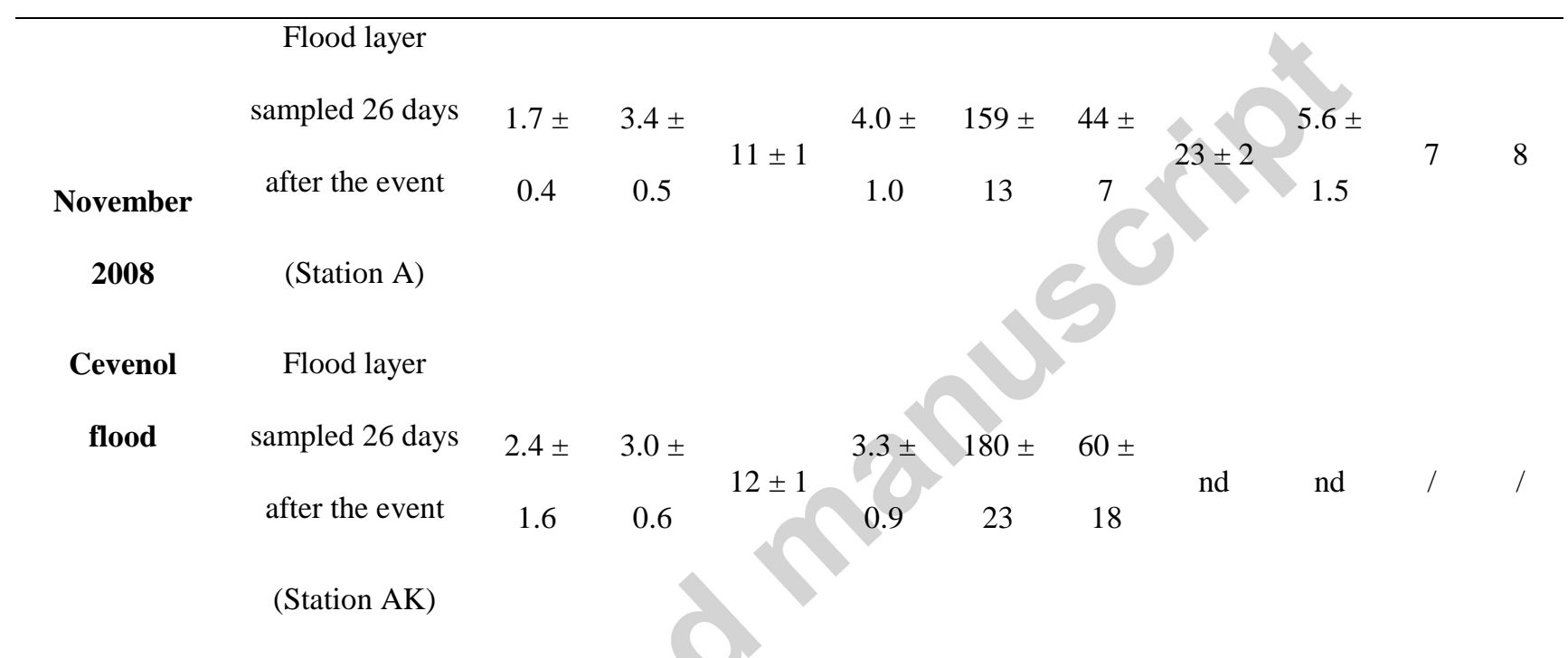

nd: no data; OC: organic carbon; IC: inorganic carbon

Table 3: Oxygen penetration depths (OPD) and diffusive oxygen uptake (DOU) measured in situ in Stations A and C during four cruises. Data are from Cathalot et al. (2010)

\begin{tabular}{|c|c|c|c|}
\hline Station & Cruise & OPD (mm) & 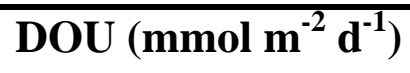 \\
\hline \multirow{3}{*}{ A } & Apr-07 & $1.4 \pm 0.2$ & $21.5 \pm 3.9$ \\
\hline & Sep-07 & $1.7 \pm 0.1$ & $15.3 \pm 1.5$ \\
\hline & Jun-08 & $5.8 \pm 0.8$ & $9.2 \pm 3.1$ \\
\hline
\end{tabular}


Apr-07

C

Jun-08

Dec-08

$5.4 \pm 0.8$

$3.4 \pm 0.7$

$9.3 \pm 3.3$

$4.7 \pm 1.5$

$10.3 \pm 3.2$

$6.8 \pm 2.8$

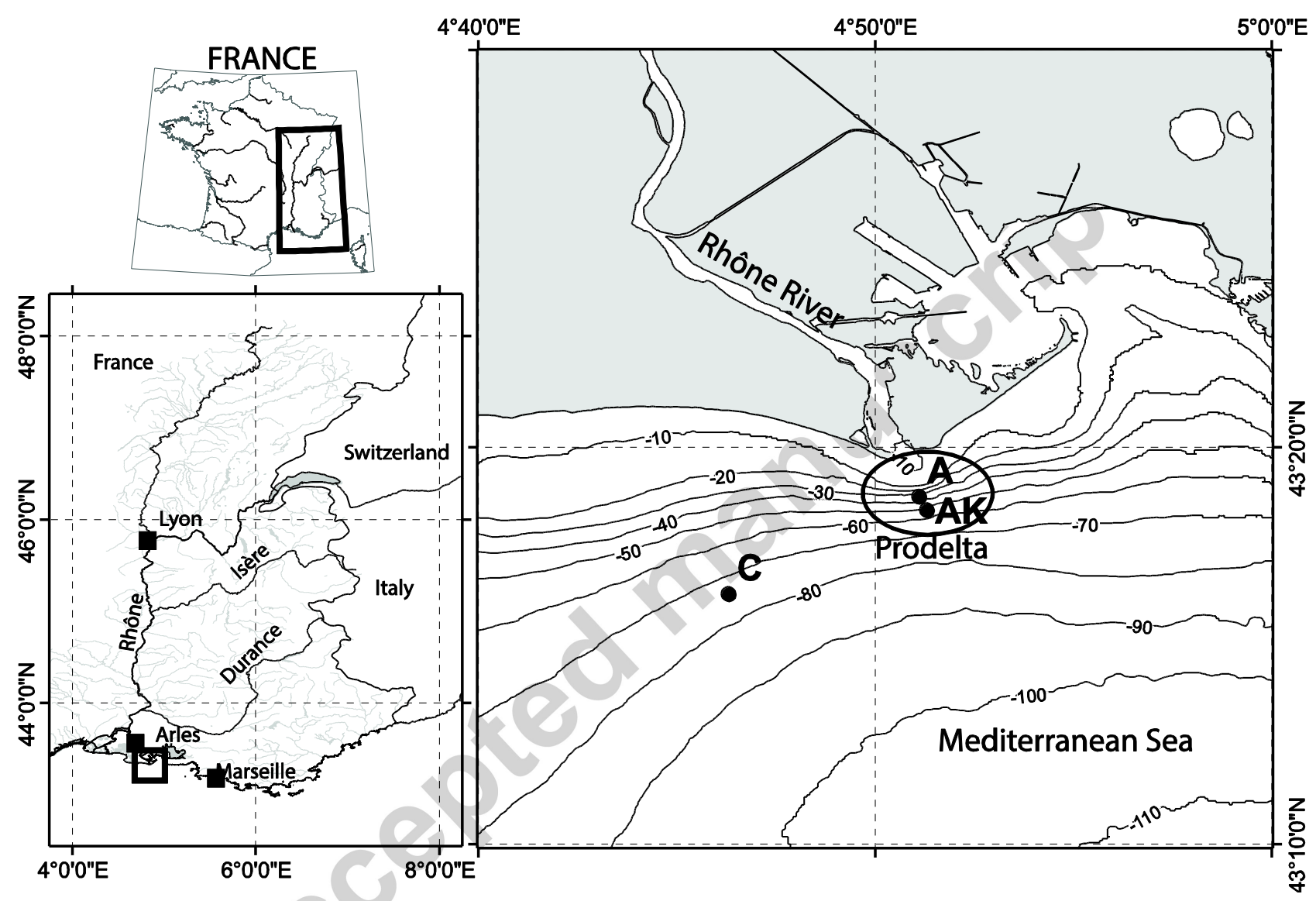



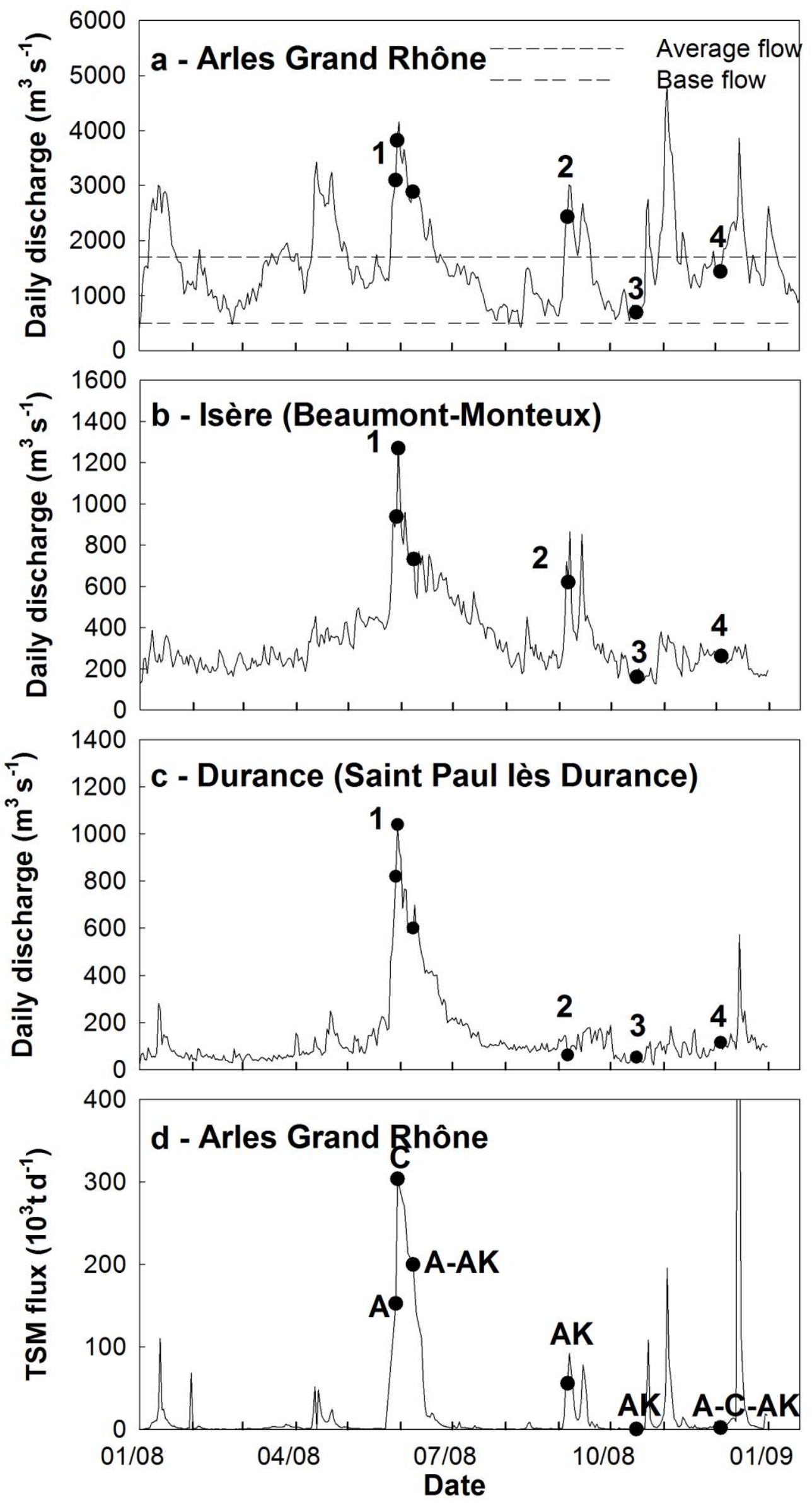


\section{Station AK}

a) 8 June 2008 - during a generalized flood

OC - IC

(\%)

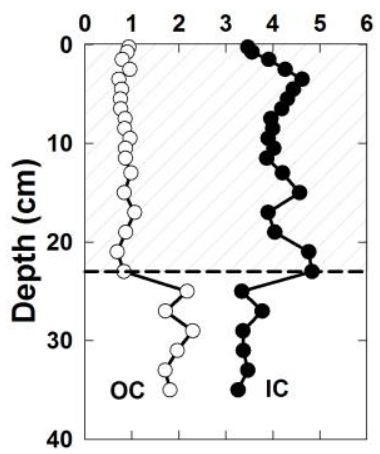

Particulate Mn

$\left(\mu \mathrm{mol} \mathrm{g}{ }^{-1}\right)$
Particulate Fe $\left(\mu \mathrm{mol} \mathrm{g}{ }^{-1}\right)$
Particulate $\mathbf{P}$ $\left(\mu \mathrm{mol} \mathrm{g}{ }^{-1}\right)$

b) 6 September 2008 - after a period of high flow rates
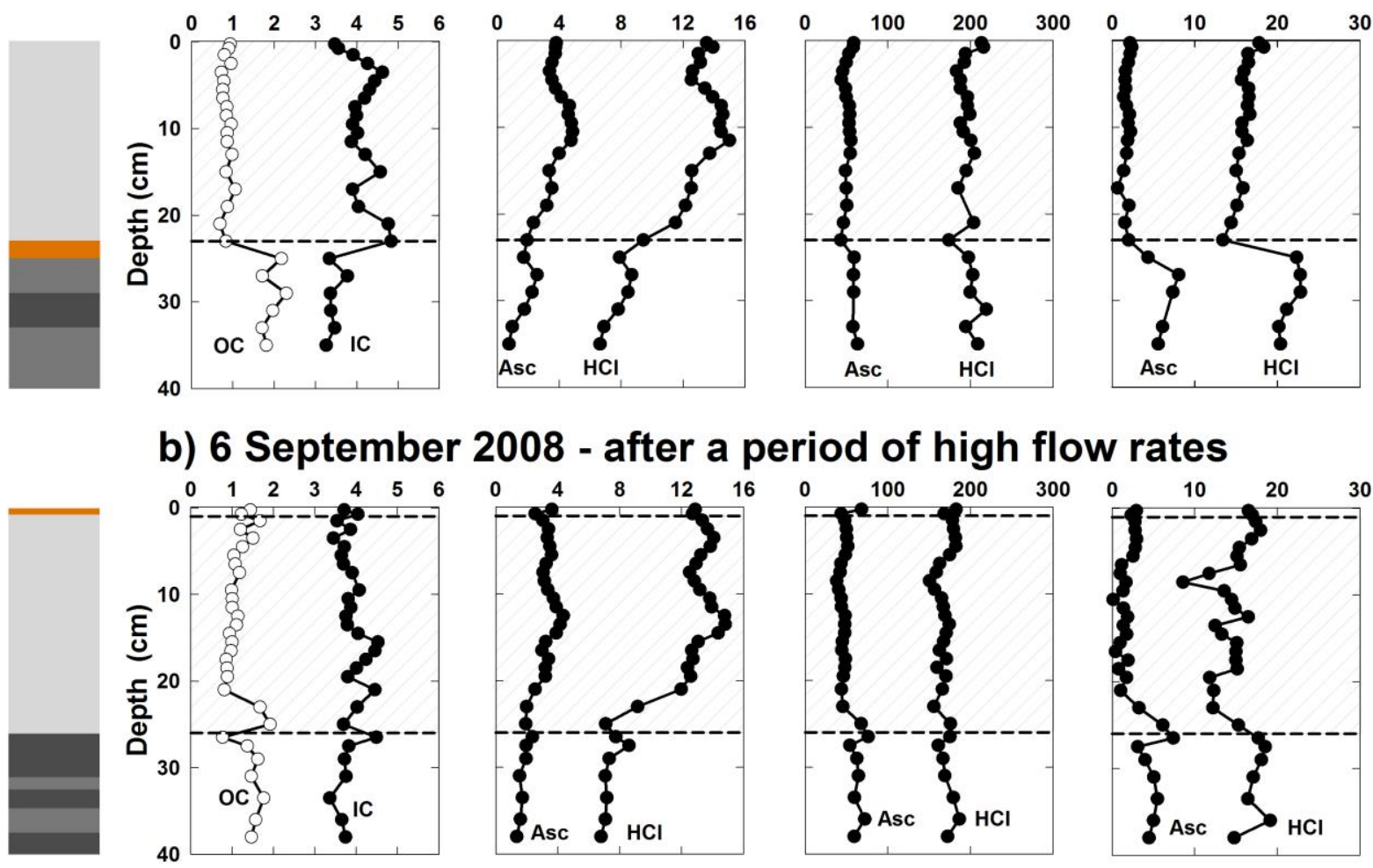

c) $\mathbf{1 6}$ October $\mathbf{2 0 0 8}$ - after a period of moderate flow rates
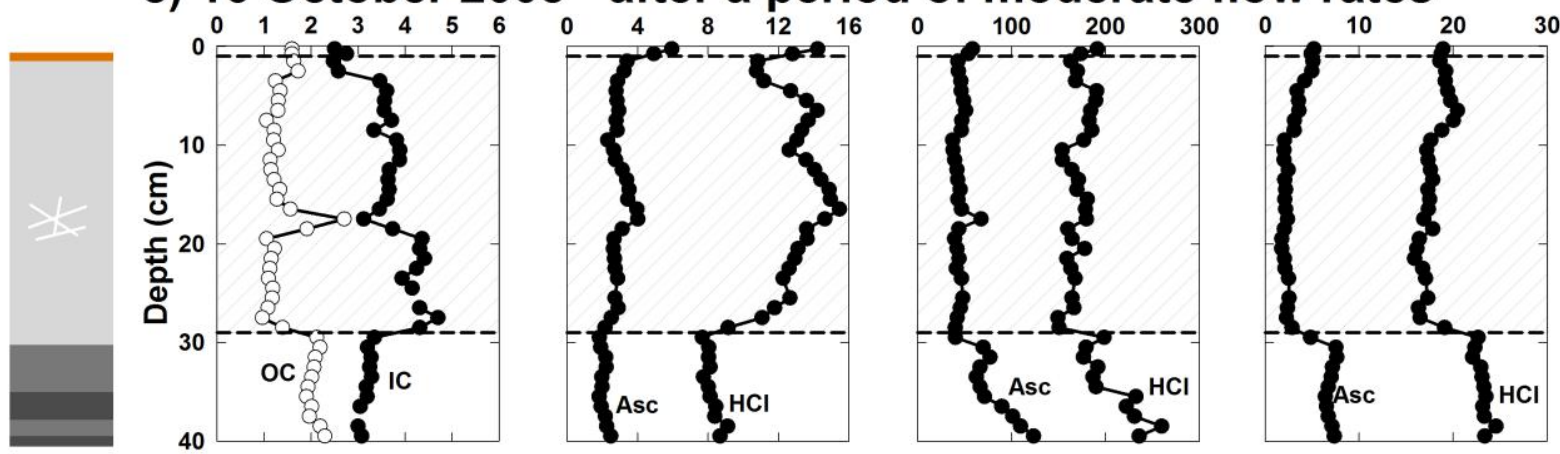

d) 4 December 2008 - 26 days after a Cevenol flood
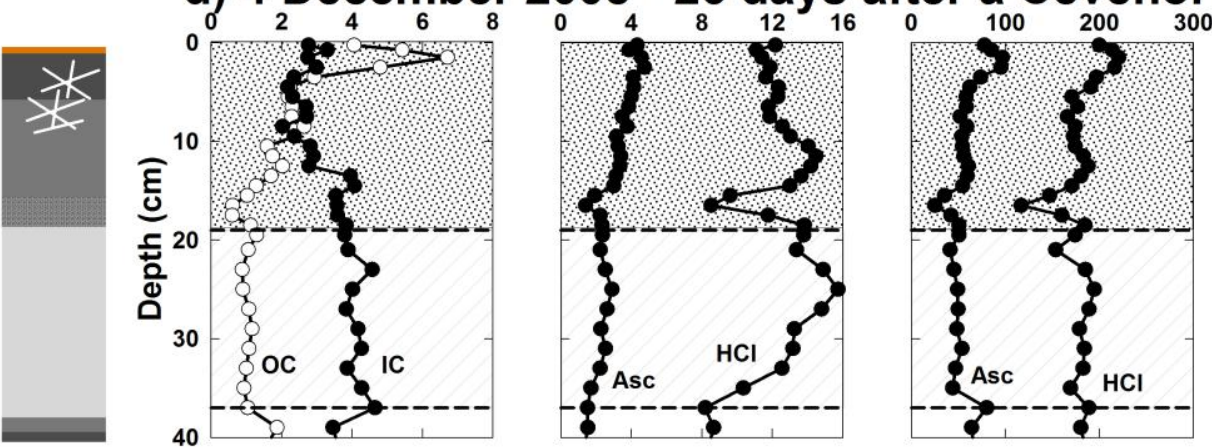

Stratigraphy legend

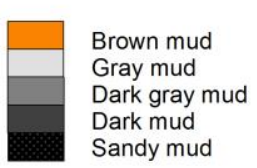

Plant fibers 


\section{STATION A}

\section{a - 20 April 2007}
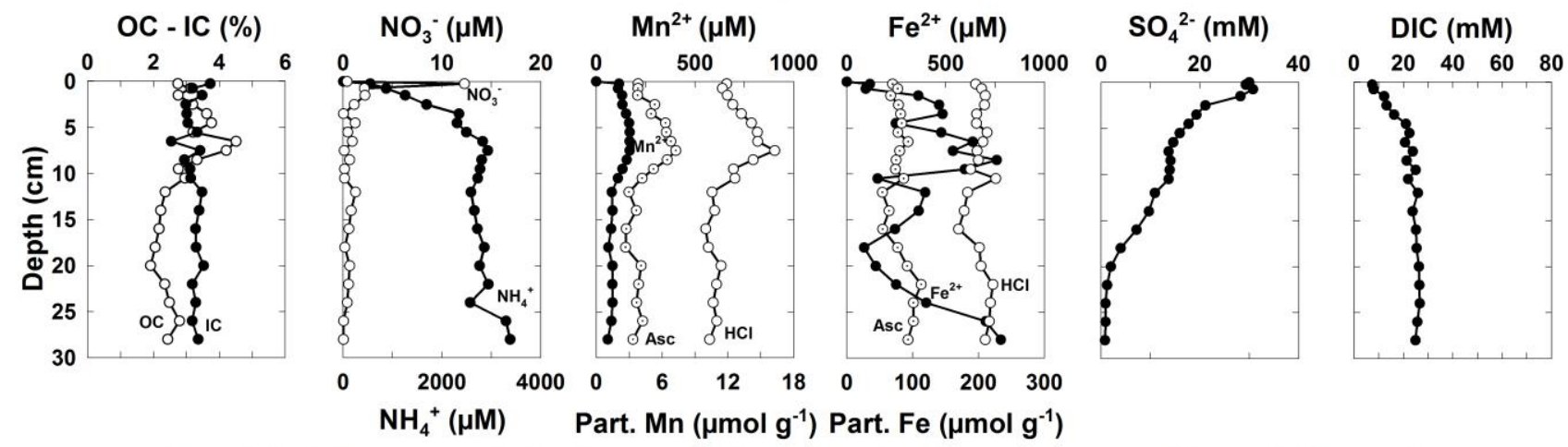

\section{b - 29 May and 8 June 08 - during a generalized flood}
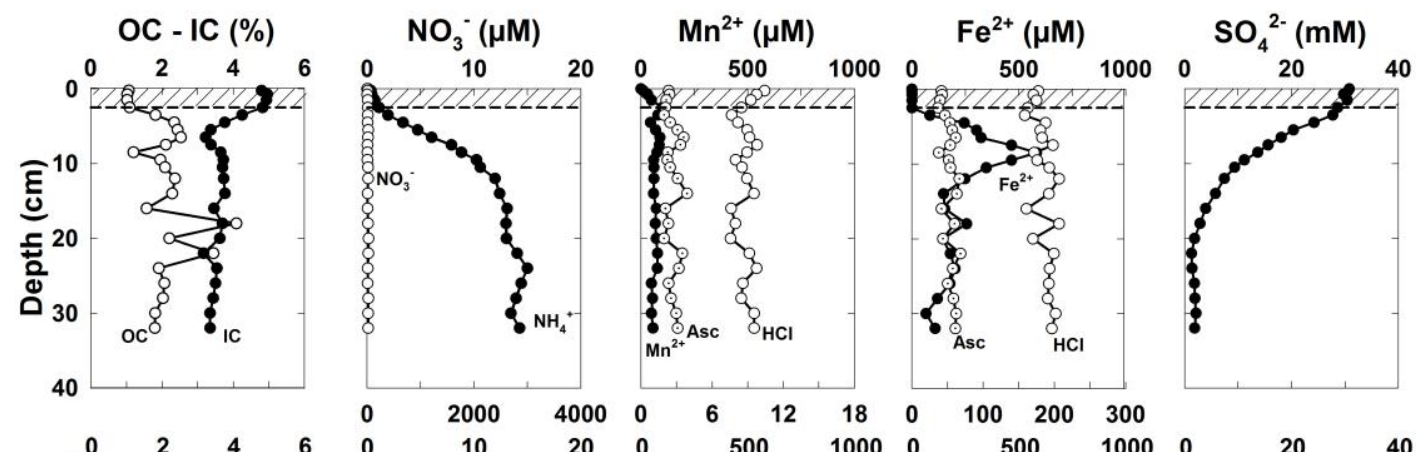

DIC (mM)
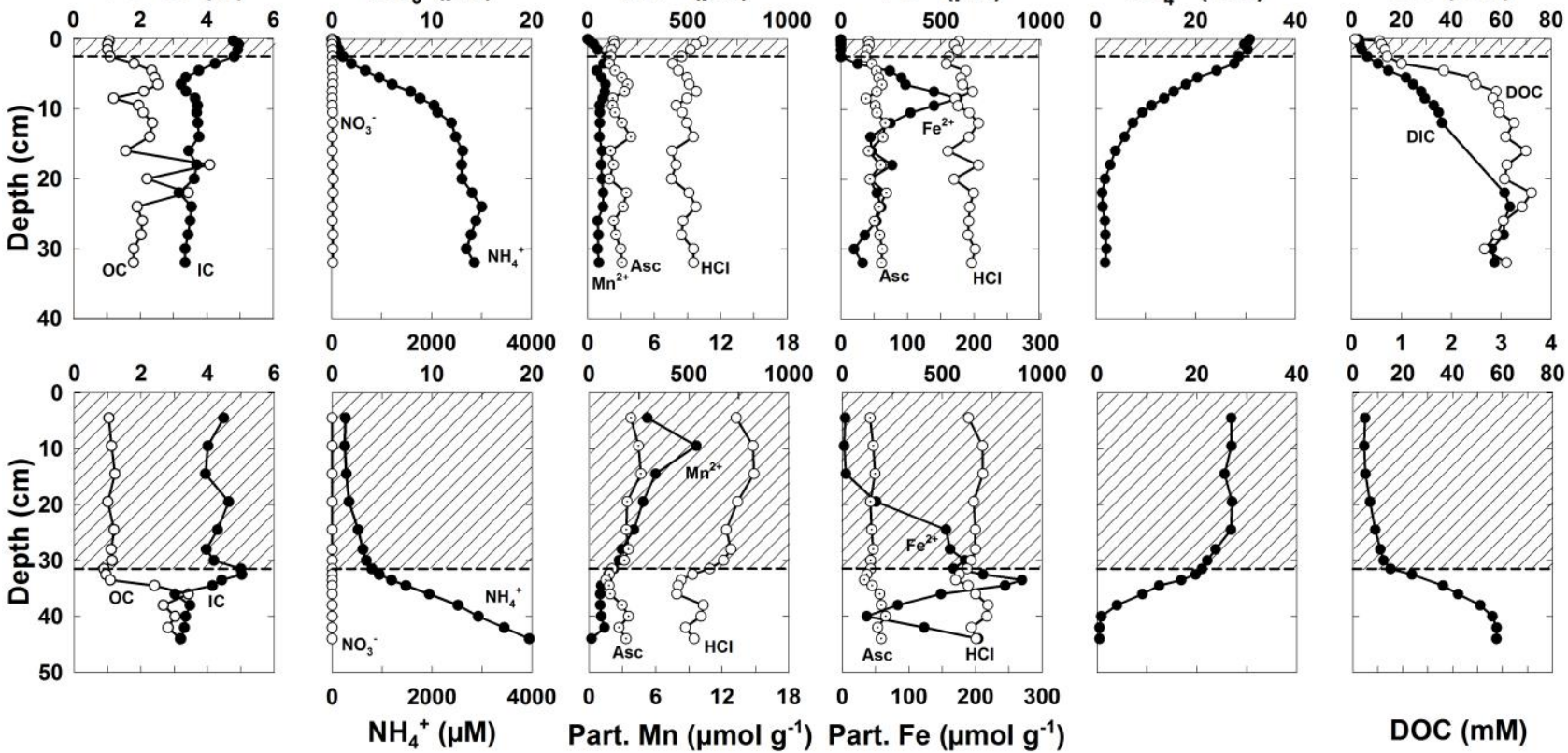

DOC (mM)

\section{C - 4 December 2008 - 26 days after a Cevenol flood} OC - IC (\%)

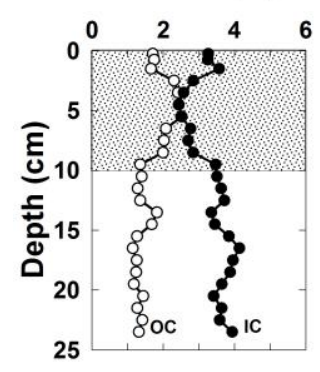
$\mathrm{NO}_{3}^{-}(\mu \mathrm{M})$

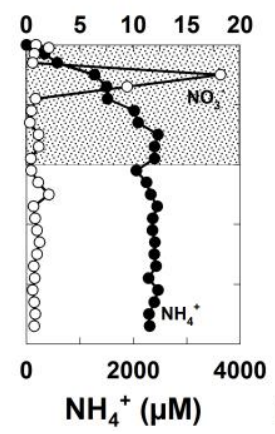

$\mathrm{Fe}^{2+}(\mu \mathrm{M})$

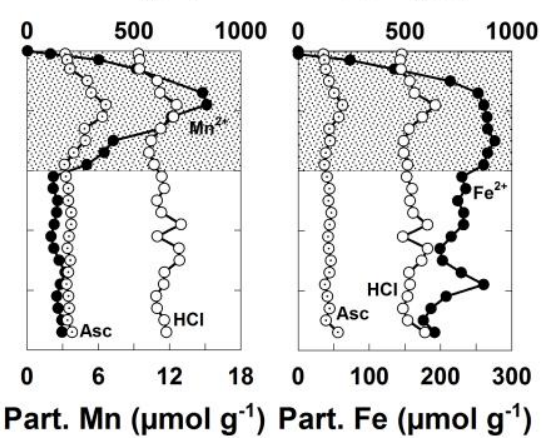

DIC (mM)
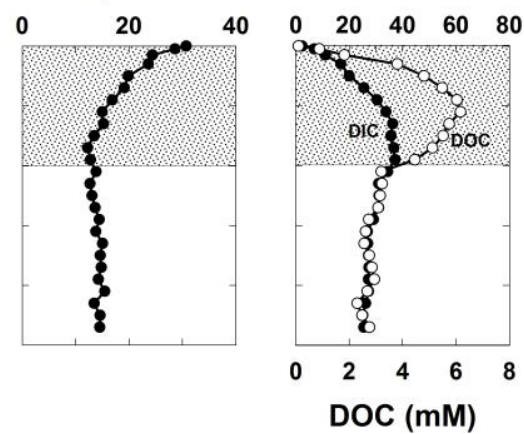


\section{STATION C \\ a - 23 April 2007}
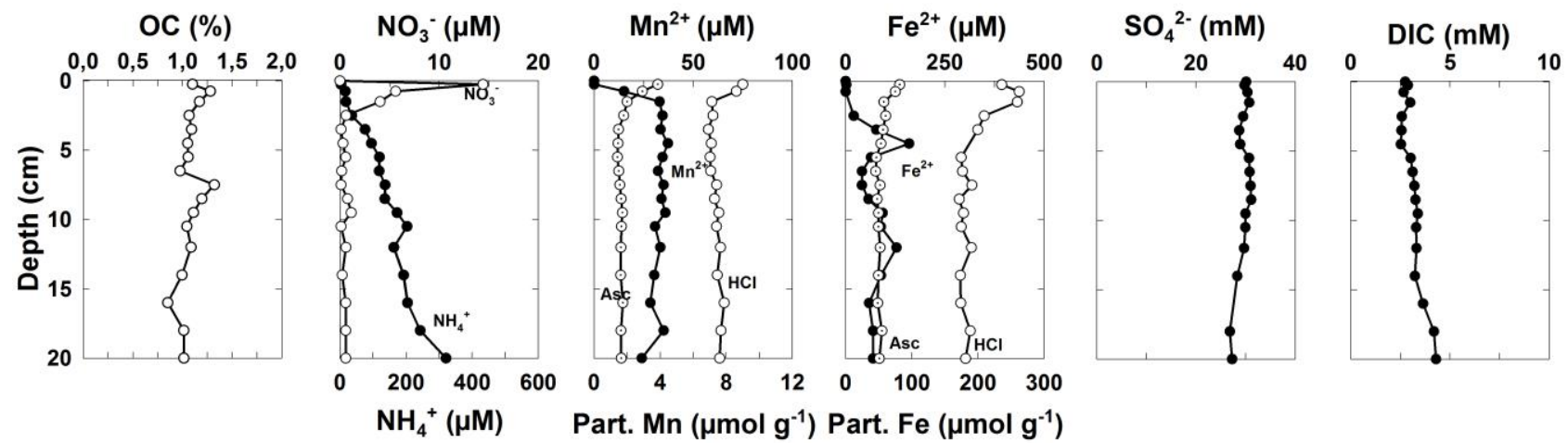

b - 30 May 2008 - during a generalized flood
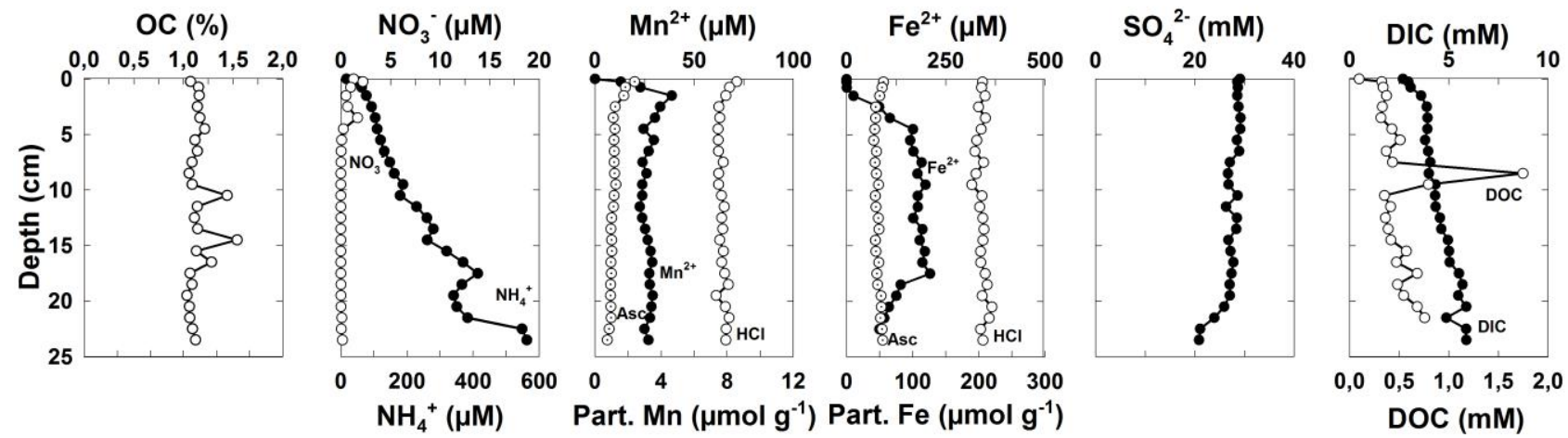

\section{c - 4 December 2008 - 26 days after a Cevenol flood}

OC (\%)
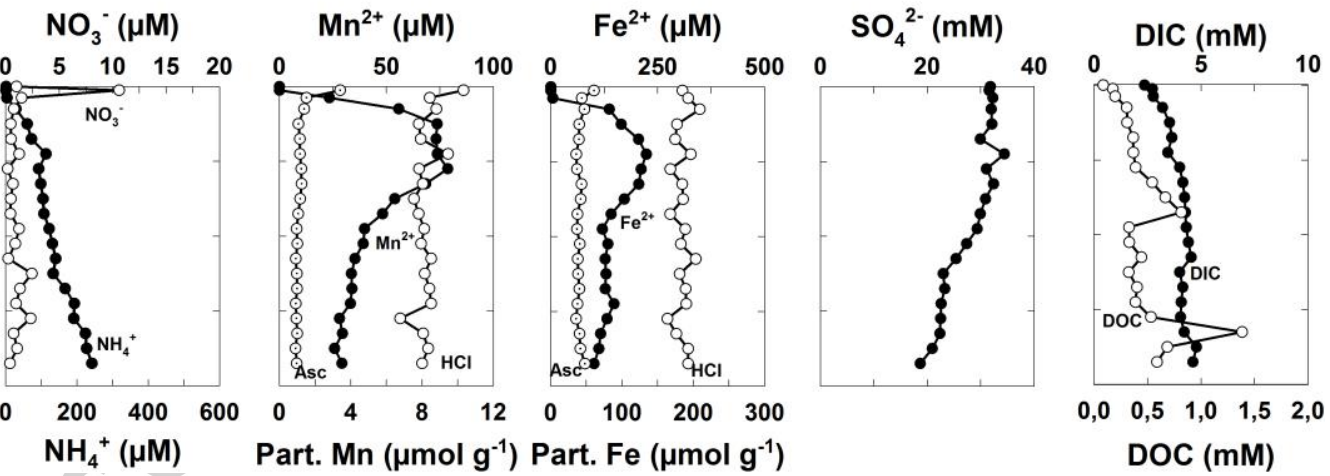


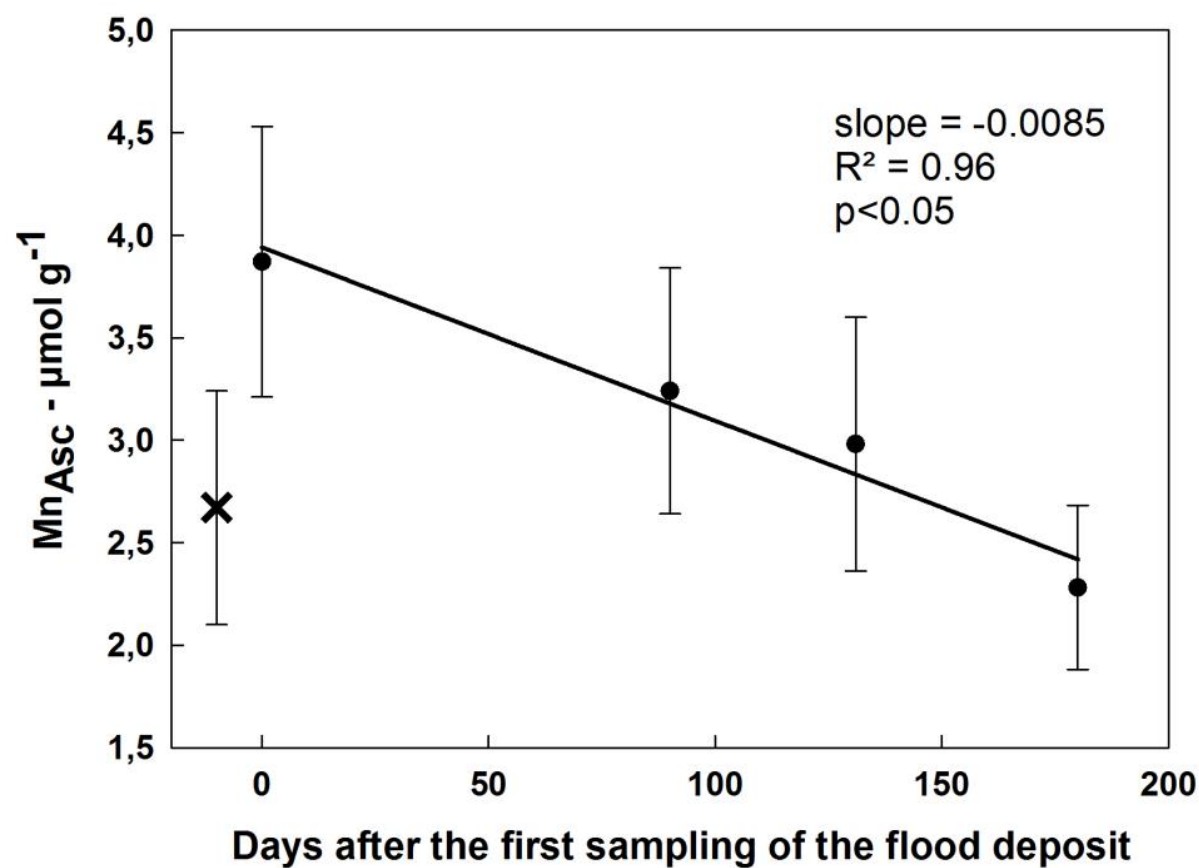




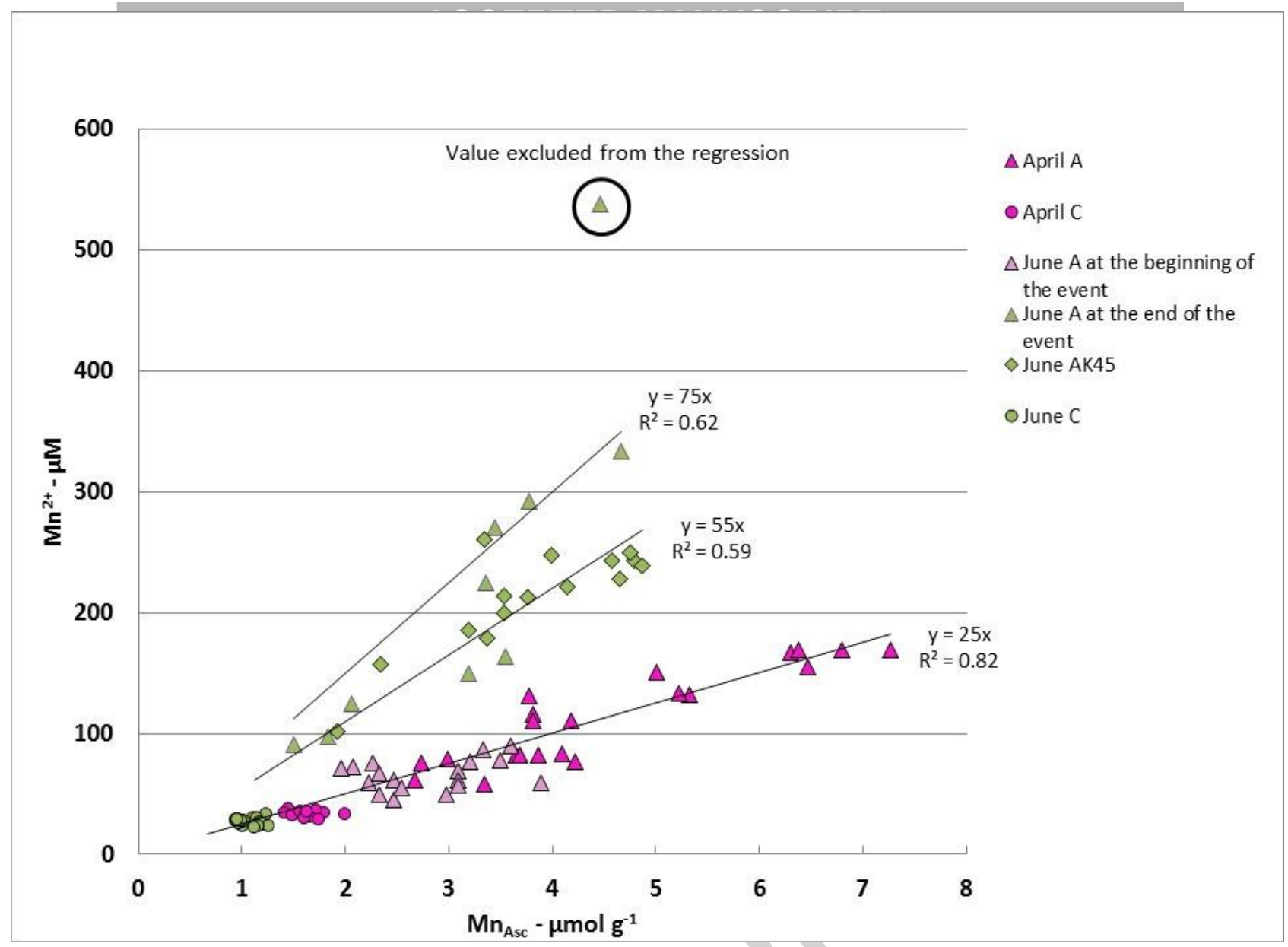

\section{Highlights}

- We investigated transient biogeochemical processes within two contrasting flood deposits

- We show that the reduction of manganese oxides is very efficient in the Rhône prodelta area

- Episodic pulsed inputs of sediments supply the area with enough oxides to completely inhibit any accumulation of free sulfide in the porewater

- Episodic pulsed inputs of sediments have impact on manganese and dissolved organic carbon outflux, and on nitrogen cycle 